\title{
Robber Barons Redux: Antimonopoly Reconsidered
}

\author{
RICHARD R. JOHN
}

The antimonopoly critique of big business that flourished in the United States during the $1880 \mathrm{~s}$ is a neglected chapter in the history of American reform. In this essay, a revised version of Richard R. John's 2011 Business History Conference presidential address, John shows how this critique found expression in a gallery of influential cartoons that ran in the New York City-based satirical magazines Puck and Judge. Among the topics that the cartoonists featured was the manipulation of the nation's financial markets by financier Jay Gould.

It has long been an article of faith among business historians that one must not, even in jest, dignify the nineteenth-century indictment of American business leaders as robber barons. This stricture was firmly impressed on me in 1981, when, as a first-year graduate student in the history of American civilization, I began to prepare for my $\mathrm{PhD}$ oral exam in business history with Alfred D. Chandler, Jr., then, as now, a towering figure in the field. It made little sense, in Chandler's view, to debate whether oil magnate John D. Rockefeller was a robber baron or an industrial statesman, as a collection of essays intended for

(C) The Author 2012. Published by Oxford University Press on behalf of the Business History Conference. All rights reserved. For permissions, please e-mail: journals.permissions@oup.com

doi: 10.1093/es/khr082

Richard R. JoHn is a Professor at the Columbia Journalism School, Columbia University, where he teaches courses in the history of communications.

Contact information: Columbia University, New York, NY. E-mail: rrj2115@ columbia.edu.

For comments on earlier drafts, I am grateful to Mark Aldrich, Noam Maggor, and Nancv R. Iohn. For research assistance, I am grateful to Amna Ahmad and 
undergraduates had proposed in 1949. "What could be less likely to produce useful generalizations"-Chandler wrote in 1984, in articulating a position he had held for many years - "than a debate over vaguely defined moral issues based on unexamined ideological assumptions and presuppositions?"2

Chandlerian business history relegated the robber baron to the dustbin of history. And there he has mostly remained, at least for business historians. With few exceptions, the collective portrait of the late-nineteenth-century business leader that has emerged from the scholarship of business historians in the past several decades has sidestepped the once heated debate that swirled around his conduct and character. ${ }^{3}$ When he was not reimagined as a Chandlerian organization builder-as, for example, in Maury Klein's Life and Legend of Jay Gould (1986), Olivier Zunz's Making America Corporate (1990), and Steven W. Usselman's Regulating Railroad Innovation (2002)-he became the beneficiary of a particular set of institutional arrangements-as, for example, in Naomi R. Lamoreaux's Great Merger Movement in American Business (1985), Richard Franklin Bensel's Political Economy of American Industrialization (2000), and Colleen A. Dunlavy's essays on the late-nineteenth century "plutocracy" $(2004,2007) \cdot{ }^{4}$ Each of these approaches has much to

1. Latham, Rockefeller. The robber baron epithet was discussed thoughtfully in a number of essays in the 1950 s (e.g., Bridges, "Robber Baron Concept"), culminating in a morally engaged survey of the debate by David Chalmers in 1961 (Chalmers, "Robber Barons"). Since 1961, however, little of consequence has been published on this topic, a tribute to the growing influence of the Chandlerian approach to business history. For the most part, the topic has been relegated to the realm of polemic-for example, Folsom, The Myth of the Robber Barons. The antimonopoly critique, in contrast, has received a thoughtful discussion in two recent publications: T. J. Stiles's Pulitzer-prize-winning biography of Comelius Vanderbilt, The First Tycoon, and Richard White's remarkable history of the first transcontinentals; Railroaded.

2. Chandler, "Comparative Business History," 7. Chandler's rejection of the robber baron-industrial statesman duality was in one sense disingenuous, since, in the main, he endorsed the business-leaderyas-industrial-statesman thesis that had been popularized by Columbia University historian Allan Nevins, albeit without its overtly moral connotations. Moral considerations, however, were rarely far from view. For Chandler, as for Nevins, big business built the economic juggernaut that enabled the Allies to vanquish the Nazis in the Second World War, an outcome that for Chandler, as for Nevins, was a moral triumph of incalculable significance. I am grateful to Noam Maggor for helping me to clarify my thinking on this point.

3. Labor historians, in contrast, have never entirely abandoned the moral critique. See, for example, Licht, Industrializing America, chap. 6.

4. Klein, Gould; Zunz, Making America Corporate; Usselman, Regulating Railroad Innovation; Lamoreaux, Great Merger Movement; Bensel, Political Economy; Dunlavy, "Citizens to Plutocrats"; Dunlavy and Welskopp, "Peculiarities and Myths." 
recommend it. Yet neither call fully explain the antimonopoly critique of business behavior out of which the robber baron evolved. This essay reconsiders the antimonopoly critique by locating the robber baron in his cultural and institutional context. It is not my intention to reopen the hoary debate over robber barons and industrial statesmen: to read this essay in this way misconstrues its intent. Rather, it is my goal to historicize this debate by explaining how it emerged and why it mattered.

The robber baron epithet was neither invented nor popularized in the western United States, as historians have long assumed, echoing a conceit championed by cultural critic Matthew Josephson. And its lineage was neither plebian nor rural. Rather, it originated along the Atlantic seaboard, in a decidedly patrician, urban milieu. Writing in 1954, Josephson reminisced that he drew the title for his 1934 expose, The Robber Barons, from "the folklore of the Kansas Greenbackers and Populists of the 1880s." In the 1962 foreword to the Robber Barons, Josephson was even more specific. "It was not I," Josephson declared, "but the embattled farmers of Kansas, who is one of their antimonopoly pamphlets of 1880 , first applied the nomenclature of Robber Barons to the masters of railway systems." ${ }^{6}$ In this, as in many matters large and small, Josephson misled his readers. In fact, a variant of the robber baron epithet can be found as early as 1859 in an editorial penned by newspaper editor Henry Raymond for the staid New York Times. Raymond's target was business magnate Cornelius Vanderbilt; Vanderbilt's business practices, in Raymond's opinion, were reminiscent of those of the "old German barons" on the Rhine. ${ }^{7}$

The characterization of certain business leaders as robber barons emerged shortly thereafter. The epithet was coined not by pitchfork wielding populists, as Josephson mistakenly claimed, but, rather, by the scions of two of the oldest and most socially respectable families in the country. Its earliest known occurrence in a business context can be found in an 1869 letter from the perceptive business analyst Charles Francis Adams, Jr., to the iconoclastic political economist David A. Wells. ${ }^{8}$ Four years later, Adams's cousin and neighbor, Josiah Quincy, Jr., invoked the epithet in a popular address. The business practice Quincy condemned was the inflation of dividend

5. Cited in Bridges, "Robber Baron Concept," 2.

6. Josephson, Robber Barons, vi.

7. Stiles, First Tycoon, 328-9. Ironically, Raymond invoked this metaphor to castigate certain practices of Vanderbilt's that were, in the main, antimonopolistic.

8. Charles Francis Adams, Jr., to David A. Wells, 14 January 1869, in Dorfman, Economic Mind, 23. "The old robber barons were children in the art of thieving-it is only now reduced to a system; poor old Rob Roy must hide his diminished head before Drew, or Vanderbilt, or Jay Gould." 
payments on railroad securities occasioned by the unwarranted increase of the railroad's capitalization, a technique known as stock watering. "The robber barons of the middle ages," Quincy sputtered, "took toll from everybody that passed, but they had not wit enough at that time to devise a plan by which they could make the whole community pay interest forever upon the money they had stolen."

Adams and Quincy had much in common. Each had extensive business experience, each hailed from a respected family with a long heritage of public service, and each was college educated, a circumstance that helped explain their familiarity with an otherwise obscure chapter in medieval German history. No less significantly, each was descended from one of the founders of the republic, a circumstance that invested their pronouncements with considerable moral authority and that assured them a wide and respectful audience. Adams was the great grandson of John Adams, a drafter of the Declaration of Independence and the second president of the United States. Few Americans had a more impressive pedigree: in addition to being the direct descendent of a founding father, Adams was also the son of the US minister to the United Kingdom during the Civil War and the grandson of the sixth US president, John Adams's son, John Quincy. Shortly after penning, his "robber baron" letter to Wells, Adams published Chapters of Erie: And Other Essays (1871), a slashing indictment of the financial jugglery of railroad baron Jay Gould. Justly admired in its own day, Adams's indictment remains, more than a century later, a landmark in American investigative journalism. In 1872, Adams accepted an appointment as chairman of the Massachusetts Railroad Commission, the first regulatory agency of its kind in the United States. ${ }^{10}$

Quincy was the grandson of a prominent Boston, Massachusetts, lawyer who, in the 1770s had vigorously defended the colony's rights in its contest with Great Britain before succumbing to tuberculosis at age 31 in April 1775, one week after the War of Independence had begun at Lexington and Concord. Had Quincy's grandfather lived, he would almost certainly have played a prominent role in the founding of the republic. (Quincy's grandfather was, somewhat confusingly, also known as Josiah Quincy, Jr., making his grandson, technically, Josiah Quincy IV.) Quincy's father was even more distinguished. Following a stint in Congress (1805-1813) and a term as Boston mayor (1823-1828), he was appointed president of Harvard College, a position he held between 1829 and 1845. Quincy, Sr., is probably best known today for his pivotal role in the establishment of the warehouse 
complex in downtown Boston that in the 1970s was transformed into the tourist mecca named in his honor Quincy Market. Quincy, Jr.who, like his father and grandfather, was a lawyer by training-also served a term as Boston mayor (1845-1849) and was for many years the treasurer of the most important railroad in Massachusetts. Quincy's business career came to an abrupt end in 1852, when, as a result of the financial collapse of a Vermont railroad in which he had invested, he lost much of his inheritance and found himself obliged to return to his legal practice. ${ }^{11}$

The medieval robber barons were renegade warlords who had defied the Holy Roman Emperor by illegally collecting exorbitant tolls on river-borne traffic, sometimes, it was alleged, by stretching iron chains across the Rhine to block the passage of vessels unwilling to pay the tax. Their heirs, in the minds of Adams and Quincy, were many of the country's railroad leaders. Though Adams and Quincy would at various points in their careers each make large investments in railroad corporations, their conception of business enterprise was shaped by what, in retrospect, one might call a pro-producerist or even an anti-investor bias. ${ }^{12}$ Like their medieval forebears, the modern robber barons blocked commerce and flaunted the law in order to extort exorbitant sums from the merchants, manufacturers, and farmers who shipped their goods through the transportation channels they controlled. The source of their wealth was not the legitimate service they provided, but, rather, the exorbitant fees that their investor-owners charged shippers to cover the cost of the dividend payments on the overvalued railroad securities in which they had invested.

The antimonopoly critique had deep roots in American public life. Older than the republic, it drew its emotional power from the principled assault on special privilege popularized by the Scottish Enlightenment political economist Adam Smith, an indictment that remained a pillar of moral philosophy in the United States during the early republic. Antimonopolists had no doctrinaire objection to organizational giantism, as business historians have long mistakenly

11. Kirkland, Men, Cities, and Transportation, 1, 177.

12. The phrase "anti-investor bias" is easily misunderstood. The investors that Adams condernned were speculators intent on manipulating the levers of power to make a quick profit. Adarns had little quarrel with the coupon-clipping rentiers (the proverbial "widows and orphans") who relied on financial securities for a steady return. The conflation of speculators with rentiers has caused confusion, and not only among historians. Nineteenth-century contemporaries also sometimes overlooked this distinction, a propensity that was encouraged by speculators like Gould who praised rentiers in order to keep the path clear for speculators like themselves. 
assumed. Giant organizations had existed since the early republic, and many Americans regarded them as a fulfillment of the promise of the revolution. Utopian socialism, it is worth recalling, was invented in the first half of the nineteenth century not in the factories of Europe, but, rather in the communitarian projects that briefly flourished in the American Middle West. In principle, antimonopolists had no objection to the vast aggregations of power and authority that business historians call "big business": in fact, they often complained that railroad and telegraph corporations were unnaturally small. Yet they remained fiercely opposed to the manipulation of the political process for economic gain and held fast to the time-honored presumption that the citizenry had an obligation to hold the powerful accountable. for their conducut and performance.

Antimonopolists could be found all across the political spectrum. Their ranks included not only well-born patricians like Adams and Quincy but also the doctrinaire libertarian joumalist William Leggett (1801-1839), the maverick telegraph promoter Henry O'Rielly (18061886), and the crusading land reformer Henry George (1839-1897). Among the most influential were the prominent New York City-based wholesalers who, in 1881, established the "Anti Monopoly League," an organization that would exert a not-inconsiderable influence on the 1884 presidential election. Democratic presidential contender Grover Cleveland could plausibly run as an antimonopolist; his Republican rival, James G. Blaine, could not. Antimonopoly also proved congenial to many of the leaders of the Populist Party that flourished in the 1890s throughout the West and South. Like Adams and Quincy, the Populists derided big business not because corporations were too large, but, rather, because they failed to maintain the low rates and high performances standards that, had they been operated for the benefit of the public and not their investors, they could have easily provided..$^{13}$

The intellectual affinities between eastern and western antimonopolists have been obscured not only by their cultural and political differences but also by Adams's pointed dismissal of midwestern railroad legislation as naïve and counterproductive. ${ }^{14}$ While substantial, these differences are easily exaggerated. Like the Populists, Adams and Quincy lauded the organizational capabilities of the railroad and telegraph while deriding their operation by opportunistic speculators like Gould; like the Populists, they questioned the efficacy of competition

13. Postel, Populist Vision, chap. 5.

14. Charles F. Adams, Jr., "The Railroad Usury Law," Nation 32 (April 14, 1881), 254; Adams, "Thurber versus Fink," Nation 32 (April 21, 1881), 273-4; Kirkland, Charles Francis Adams, Jr., 55-6. 
as a counterweight to monopoly; and, like the Populists, they looked to the government to check speculative excess.

While the origins of the robber baron epithet were literary, its most compelling expression was visual, a circumstance that has obscured its significance, since most historians typically neglect images in favor of words. Its locus classicus was the remarkable gallery of satirical cartoons published during the 1880s in the influential New York City-based weekly satirical magazines, Puck and Judge. ${ }^{15}$ Each of these magazines was managed in this period by a cartoonistJoseph Keppler at Puck, James A. Wales at Judge-and each was known primarily for the three original full-page cartoons that appeared every week: one on the front cover, one on the back cover, and one two-page spread in the centerfold. ${ }^{16}$ In the 1880 s, the decade in which the robber baron became firmly enshrined in American visual culture, Puck and Judge ran dozens of cartoons savaging Jay Gould, William $\mathrm{H}$. Vanderbilt (Cornelius's son), and other like-minded business leaders as reckless monopolists unmindful of the public good.

Cartoons are an underutilized source for the historian. This is unfortunate, since they typically conveyed their message with economy and vigor, making them highly effective in shaping public opinion and advançing public debate. In addition, their imagery was often vivid and compelling, making them a well-spring for a visual iconography that can endure for generations. ${ }^{17}$. The business-related cartoons that ran in Puck and Judge during the 1880 s did much to popularize the antimonopoly critique of special privilege while establishing a visual iconography that would long inform the popular conception of big business in the United States.

The role of Puck and /udge in late-nineteenth-century American public life was roughly analogous to that of the British comic magazine

15. Of the several late-nineteenth-century publications other than Puck and Judge that featured antimonopoly cartoons, the most important were the New York Daily Graphic and Wasp. Each was a pioneer. The Daily Graphic had run numerous black-and-white line drawings on business topics ever since its founding in 1873, while Wasp was the first American magazine to print cartoons in full color. Neither publication, however, could match the cultural influence of Puck and Judge. The heyday of the Daily Graphic in the 1870s antedated the emergence of antimonopoly as a national political issue, while Wasp was published in San Francisco, far from the nation's leading publishing centers.

Several full-color galleries of Puck and Judge cartoons on business topics, including antimonopoly, can be found on the web. See, for example, Cox, "Known Lithographic Caricatures"; National Humanities Center, "Image of the Octopus"; and Aldrich, "Railroad Cartoons."

16. Wales worked as cartoonist for Puck before decamping to found Judge in late 1881; he drew antimonopoly cartoons for both magazines.

17. Kemnitz, "The Cartoon as a Historical Source," 84-5. See also Culbertson, "Golden Age of American Political Cartoons" and Thomas, "Cartoons," 
Punch, on which they were modeled and can be compared to that of the present-day television comedy programs "The Colbert Report" and "The Daily Show with Jon Stewart." The circulation of Puck in the 1880s hovered around 80,000, with Judge not far behind. ${ }^{18}$ In the 1884 presidential campaign, as well as the several that followed, Puck and Judge exerted, in the words of one well-informed contemporary, an influence on the "politics of the country" that was "probably greater than that of all the daily press combined": "Their weekly cartoons were awaited eagerly, were passed from hand to hand, and were the subject of animated comment in all political circles." ${ }^{19}$ The political salience of Puck and Judge was at its peak in the run-up to the 1884 presidential election, a contest in which the New York City vote was critical and the two political parties were closely matched. In fact, it has long been plausibly contended that the election outcome in New York state, and, therefore, the nation, had been determined by a gallery of pointed Puck cartoons ridiculing the Republican presidential contender James $G$. Blaine as a "tattooed man" with a morally dubious past. ${ }^{20}$

Puck and Judge cartoons combined pointed social commentary with a recent technical advance known as chromolithography. Chromolithography made it possible to reproduce multicolor images rapidly and in large.numbers. Puck and Judge were two of the first magazines in the country to publish in color as well as black and white, a distinction that set them apart from their peers and gave them much of their cultural cachet. Puck ran its first chromolithographic cartoons in 1879; Judge beginning with its first issue in 1881. ${ }^{21}$ To this day, cartoons that originated in Puck and Judge enliven US history textbooks, undergraduate lectures, and the occasional academic monograph, including, for example, Louis Galambos's Public Image of Big Business in America (1975), which featured on its front coverunfortunately in black and white, rather than color--an 1890 Puck cartoon depicting a grasping "King Monopoly."22

Cultural historians have begun to explore the treatment by Puck and Judge cartoonists of certain cultural and political themes, including popular politics and anti-Catholicism. ${ }^{23}$ The cartoonists' antimonopoly critique of American business, however, bas gone largely unremarked. This is unfortunate, since this critique provides

18. Hess and Northrup, Drawn and Quartered, 60. The political influence of Puck and Judge during the final two decades of the nineteenth century, Hess and Northrup concluded, would be "hard to overestimate," 65 .

19. Bishop, Our Political Drama, 156.

20. Dewey, Art of IIl Will, 35.

21. Mott, History of American Magazines 3, 522.

22. Louis Dalrymple, "And He Asks for More!" Puck 27 (May 7, 1890): centerfold.

23. Thomas, "Mugwump Cartoonists, the Papacy, and Tammany Hall,". 
a generally well-informed and often quite revealing glimpse at a constellation of business practices that troubled the well-educated, commercially oriented, urban audience for which they were intended.

For the cartoonists of Puck and Judge, antimonopoly was an obsession. Two visually arresting cartoons from Puck illustrate how this theme was portrayed. The first, from 1882- "Our Robber Barons" -cast several of the country's $\sim$ wealthiest business leaders as medieval "robber barons" (figure 1). Prominent among them were Gould and Vanderbilt, businessmen whose identities would have been instantly recognizable to readers familiar with the visual iconography that had been featured for several years in the New York Daily Graphic. The robber barons' victim was identified merely as the "taxpayer," a kind-of everyman waylaid by Gould, Vanderbilt, and their co-conspirators to fill their coffers. The taxes the cartoonist referred to had been levied not by the government, but, rather, by the corporations Gould and Vanderbilt controlled: and, in particular, by the hefty fees their corporations charged their customers to transport information, people, and goods. The robber barons' stronghold was "Castle Monopoly," which they defended not by outmanaging their rivals, but, rather, by obtaining morally dubious political favors, which were symbolized by the ascending set of steps leading up to their stronghold that the cartoonist labeled "lobbyism," "friendly judges," and "land grants," the modern equivalent of the iron chain that the medieval robber barons had stretched across the Rhine to block the channel of trade. ${ }^{24}$

The second cartoon, also from 1882, portrayed railroad magnate William $\mathrm{H}$. Vanderbilt rebuffing his critics by bluntly proclaiming "the public be damned" (figure 2). Vanderbilt's victim was the American people, rendered by Puck cartoonist Frederick B. Opper as an American eagle, upon which Vanderbilt had stomped his foot. Powerless to intervene were Vanderbilt's watchdogs-- "Congress" and the "legislature"--whom he kept on a very tight leash. The amorality of Vanderbilt's business creed was clarified by the statements inscribed on the three plaques mounted on the wall: "I don'tțake any stock in this silly nonsense about working for anybody's good but our own"; "When we make a move it is because it is our interest to do so"; and, more cryptically, "I always find the AntiMonopolists come the cheapest." 25 The third statement underscored

24. T. Bernhard Gillam, "Our Robber Barons," Puck 11 (June 14, 1882); centerfold.

25. Frederick B. Opper, "'The Public be Damned!" Puck 12 (October 18, 1882): front cover. A similar cartoon was featured shortly thereafter in Judge, in which Vanderbilt declared, even more provocatively, "the poor be $d$ James A. Wales, "The Monopolists' Thanksgiving," Judge 3 (December 2, 1882): front cover. 


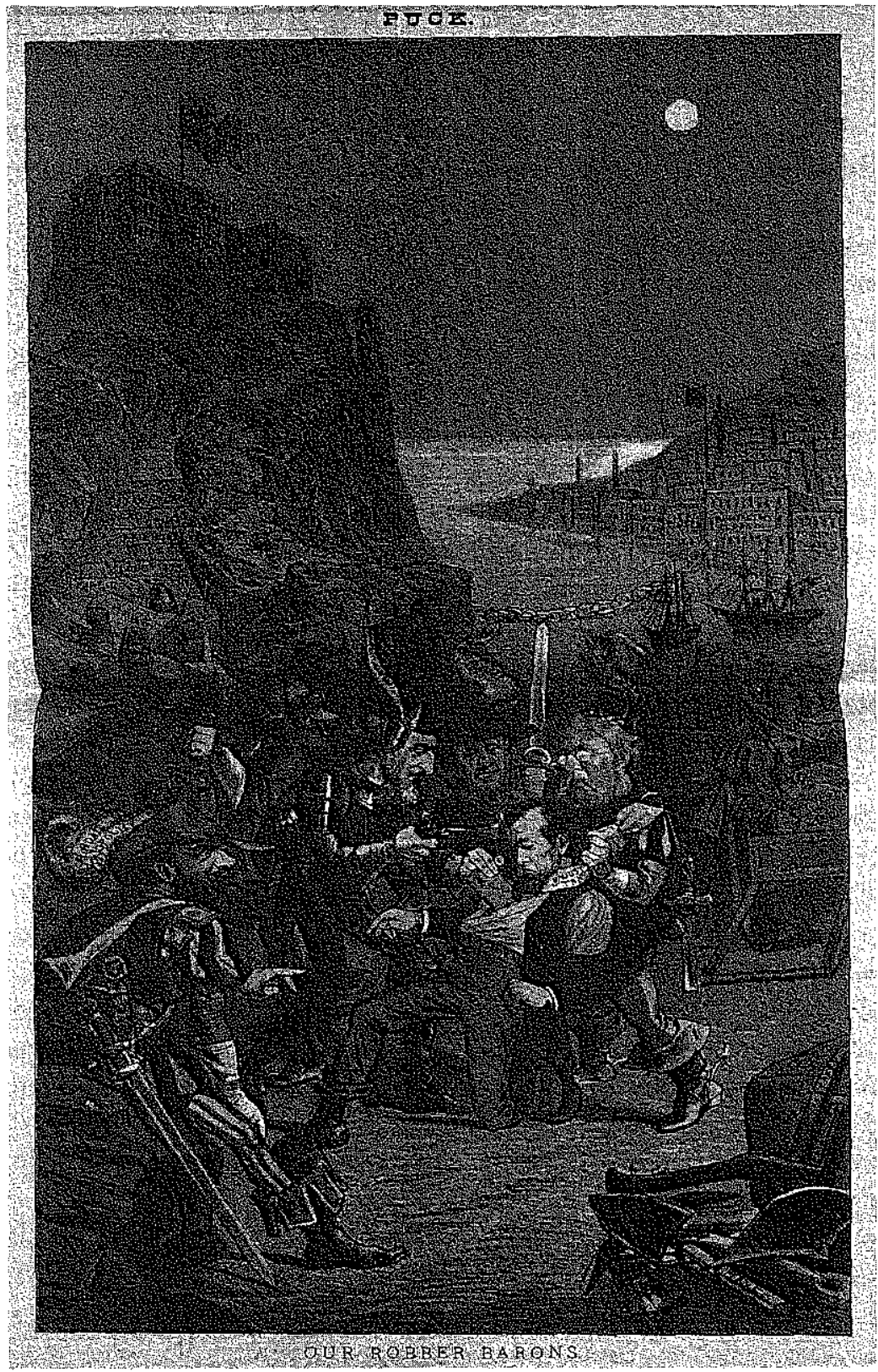

Figure 1 "Our Robber Barons" as portrayed by a Puck cartoonist in 1882. Note the iron chain in the middle background impeding the channels of trade. According to legend, medieval German warlords blocked merchants unwilling to pay their extortionate tolls from passing up and down the Rhine. T. Bernhard Gillam, "Our Robber Barons," Puck 11 (June 14, 1882): centerfold. 


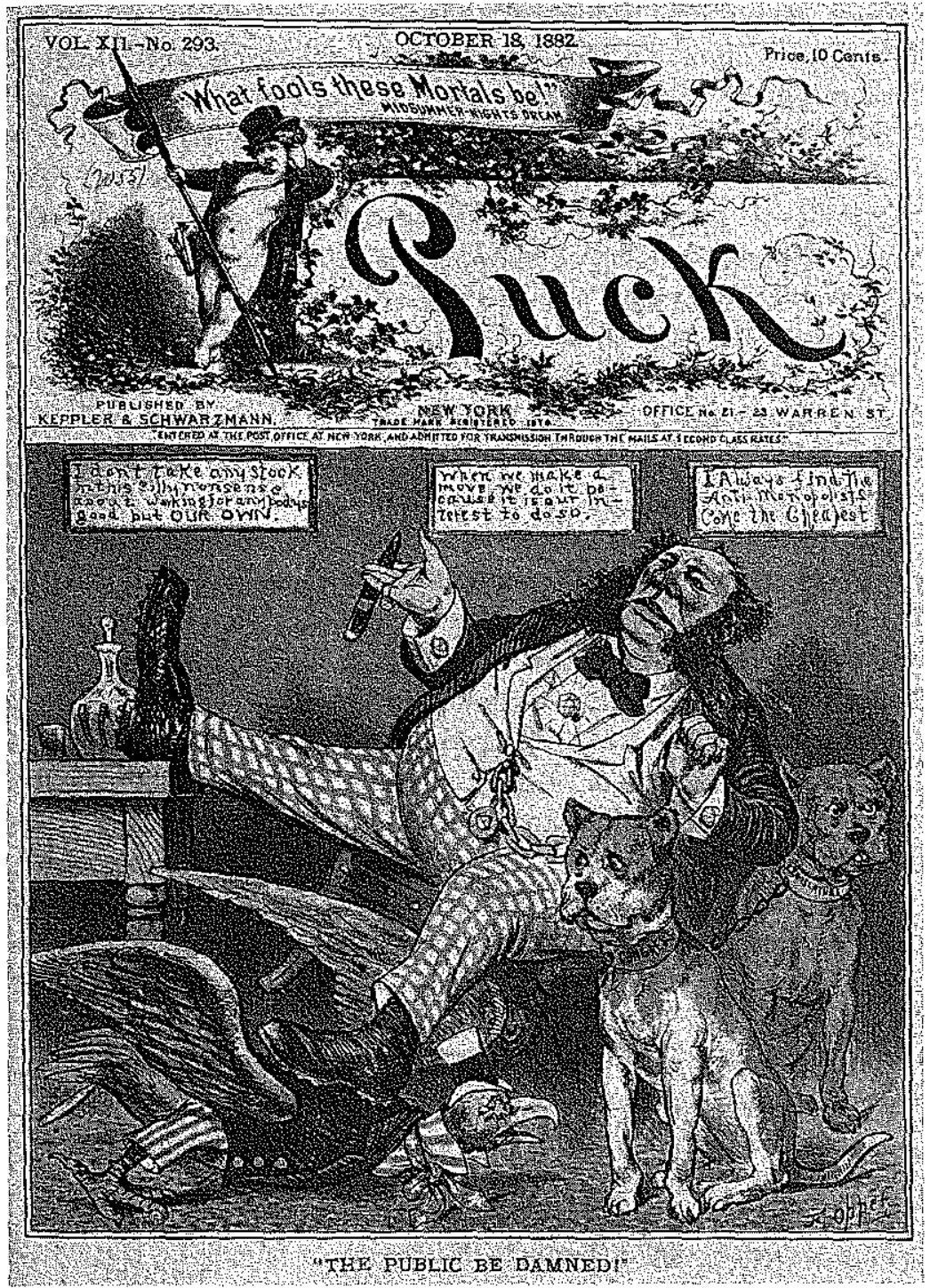

Figure 2 Railroad leader William $\mathrm{H}$. Vanderbilt was a favorite target of Puck cartoonists in the 1880s. Here he was portrayed as an overstuffed miltionaire openly contemptuous of the many critics who insisted that business leaders had an obligation to promote the public good. Frederick B. Opper, "The Public Be Damned!'" Puck 12 (October 18, 1882): front cover.

Opper's awareness of the often opportunistic cast of the antimonopoly critique, a critique sometimes brandished by venal members of New York Gity's Democratic political machine Tammany Hall to broaden their constituency and shake down politically vulnerable corporations. 
Puck and fudge occasionally depicted giant organizations as predatory creatures stalking their prey. Telegraph network provider Western Union and telephone holding company American Bell became spiders and John D. Rockfeller's oil refining business a monstrous octopus, a characterization that, in Judge, dated back to $1884 . .^{26}$ Yet organizational giantism was not the cartoonists' primary concern. Almost without exception, they were troubled less by the scale of the organizations that they skewered than by their owners' dubious business practices and lack of accountability. The United States had by 1880 boasted giant organizations for almost one-hundred years, of which at least one-namely, the Erie Railroad-had been depicted on an organization chart as a fecund, and decidedly unmenacing, flowering tree as early as $1854 .{ }^{27} \mathrm{In}$ fact, one of the most persistent complaints about Western Union and American Bell was not that they were unnaturally large, but, rather, that they were artificially small, and, thus, incapable of realizing their technical potential. ${ }^{28}$

The antimonopoly critique of American business in the $1880 \mathrm{~s}$ focused primarily on three sectors: transportation, communications, and energy. This essay focuses on communications, a topic that has been relatively neglected. And in particular, it takes as its theme the journalistic assault on telegraph giant Western Union and telephone giant American Bell.

The takeover of Western Union by financier Jay Gould in January 1881 transformed public attitudes toward antimonopoly in the telegraph business. Prior to Gould's takeover, many if not most of Western Union's critics regarded antimonopoly legislation as an effective regulatory tool. It was by no means a foolish conclusion: After all, the country's two most important telegraph laws--namely, the New York Telegraph Act of 1848 and the National Telegraph Act of

26. Frederick B. Opper, "Justice in the Web," Puck 17 (July 22, 1885): front cover; Grant E. Hamilton, "In the Clutch of a Grasping Monopoly;" Judge 14 (April 7, 1888): back cover; Frank Beard, "The Monster Monopoly," Judge 6 (July 19, 1884): back cover.

27. "New York and Erie Railroad Diagram Representing a Plan of Organization" (1855), Prints and Photographs Division, Library of Congress, Washington, DC. This remarkable image, the oldest known organizational chart of a major American corporation-a document that Chandler searched for but never located-is reproduced and analyzed in Wrege and Sorbo, "A Bridge Builder Changes a Railroad," 183-218.

28. For a related discussion, see Lipartito, "Utopian Corporation." The propensity of nineteenth-century Americans to invest such enormous expectations in giant corporations, Lipartito contended, had a utopian dimension that was traceable to the widespread enthusiasm for voluntary associations "unencumbered by tradition." Giant corporations were "meant to find freedom and democracy in a hierarchical bureaucracy": "They were to liberate by rationalizing and systematizing. It was a project that only true utopians could have imagined" (111). 
1866-had each emboldened insurgent network providers to challenge incumbents. It was, thus, not surprising that antimonopoly legislation was the expedient favored by the New York Daily Graphic cartoonist who in 1875 depicted Western Union's president William Orton, cast as the Roman God "Jupiter Ammonopoly," trampling on the goddess liberty, a stand-in for the newspaper press. Orton had refused to provide equal access to his telegraph network for newsbrokers other than the New York Associated Press (NYAP); to remedy this situation, the cartoonist urged the enactment of federal legislation empowering rival telegraph network providers to compete with Western Union. ${ }^{29}$

Gould's 1881 takeover of Western Union prompted large numbers of contemporaries to question for the first time the utility of antimonopoly legislation as a regulatory tool. It was not hard to see why. Gould raided Western Union on two separate occasions in the 1870s. Each time, Gould loudly proclaimed himself an antimonopolist and used existing antimonopoly legislation to weaken his rival. Now that Western Union had come under Gould's control, everything changed: the country's most vociferous antimonopolist had become, at least in the public mind, its most rapacious monopolist. This confusing turn of events furnished the theme for an 1881 Harper's Weekly cartoon. "Death to Monopoly!" proclaimed a youthful Hercules intent on subduing the telegraph ogre with a club labeled "competition." No longer, however, could the cartoonist take-it-for-granted that insurgents would be able to challenge the incumbent. To make this point, he paired Hercules with an elderly bystander who, as "Uncle Sam," personified the public good. "That's right, my boy," replied Uncle Sam: "That's the way to crush him; and if you fail, I'll see what I can do."30

Journalistic revulsion toward Gould was a recurrent theme in Puck and Judge. In image after image, cartoonists portrayed Gould as a machiavellian financier who lined his pockets by stifling trade, destroying rival investors, manipulating the press, and corrupting the courts. Two masterful cartoons set the tone. Each was the work of Puck's most gifted cartoonist, Joseph Keppler, and each was created in the months immediately following Gould's takeover of Western Union. In the first cartoon, Keppler depicted Gould as a satanic scamp comfortably perched on a swing labeled "telegraph monopoly" that was held up by telegraph wires that were, quite literally, strangling commerce and the press (figure 3). In Gould's back pocket were the two powerful New York City newspapers in which he had invested, and over which he was widely presumed to exert editorial control,

29. Theodore Wust, "Jupiter Ammonopoly Orton and his Victim the Press," New York Daily Graphic 7 (March 24, 1875): front cover.

30. T. Bernhard Gillam, "Death to Monopoly!" Harper's Weekly 25 (February 12,1881 ), front cover. 


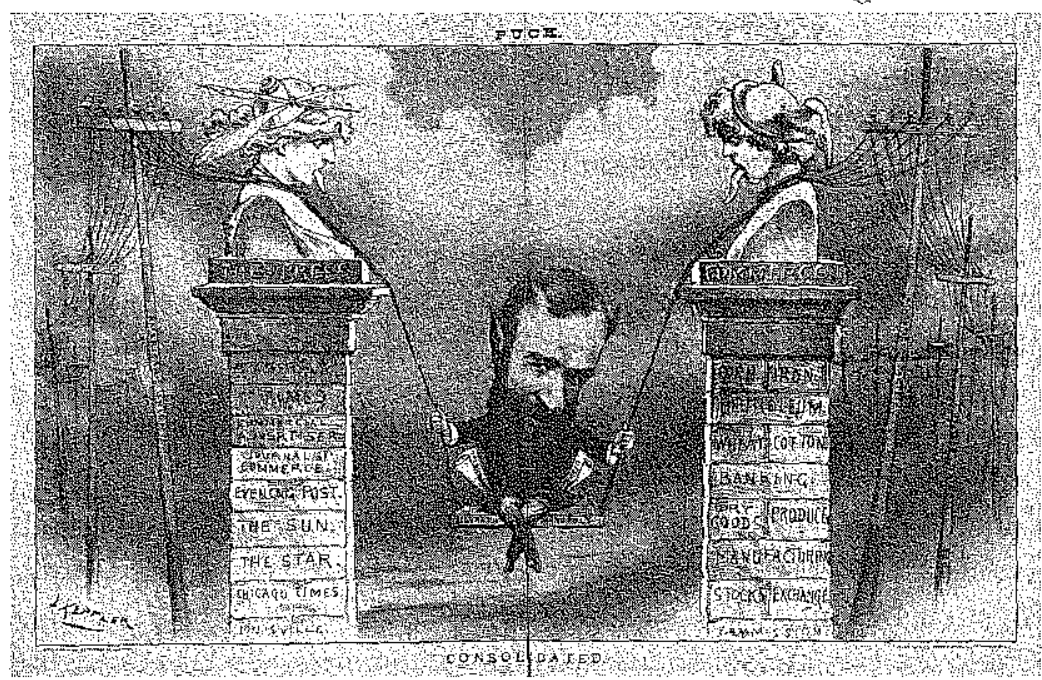

Figure 3 Jay Gould's takeover of Western Union in January 1881 outraged business leaders and journalists who feared, by no means implausibly, that Gould would use his power over the country's electrical communications network to manipulate financial markets. In this vividly realized cartoon, Gould revels in his newly acquired power over commerce and the press. Joseph Keppler, "Consolidated," Puck 8 (January 26, 1881): centerfold.

namely, the Tribune and the World ${ }^{31}$ The significance of this detail would not have been lost on Puck's media-savvy readers. The Tribune and the World were two of the seven New York City newspapers with an ownership stake in the NYAP. Should Gould acquire two more NYAP newspapers, the nation's largest newsbroker would come under his control.

In the second Keppler Gartoon, Gould and his fellow Western Union investor William $H$. Vanderbilt became telegraph linemen who, now that they had gained control of Western Union, were intent on strangling a hapless Uncle Sam, who was once again a stand-in for the public good. The cartoon was entitled "The Two Philanthropists," a sardonic allusion to the presumption that Gould's takeover of Western Union might in some way benefit someone other than its investors (figure 4). "Don't fret, Uncle Sam," Gould and Vanderbilt told their helpless victim, as they garroted him with telegraph wire, "we only want to make a bigger man of you." Keppler was unconvinced. Gould and Vanderbilt's empire, he reminded viewers, now embraced

31. Joseph Keppler, "Consolidated," Puck 8 (January 26, 1881): centerfold. "No country can be called free"-Puck's editor explained, in commenting on Keppler's cartoon-" "where it is possible for a private individual to acquire as his own personal property all the means of communications among its citizens" (346). 


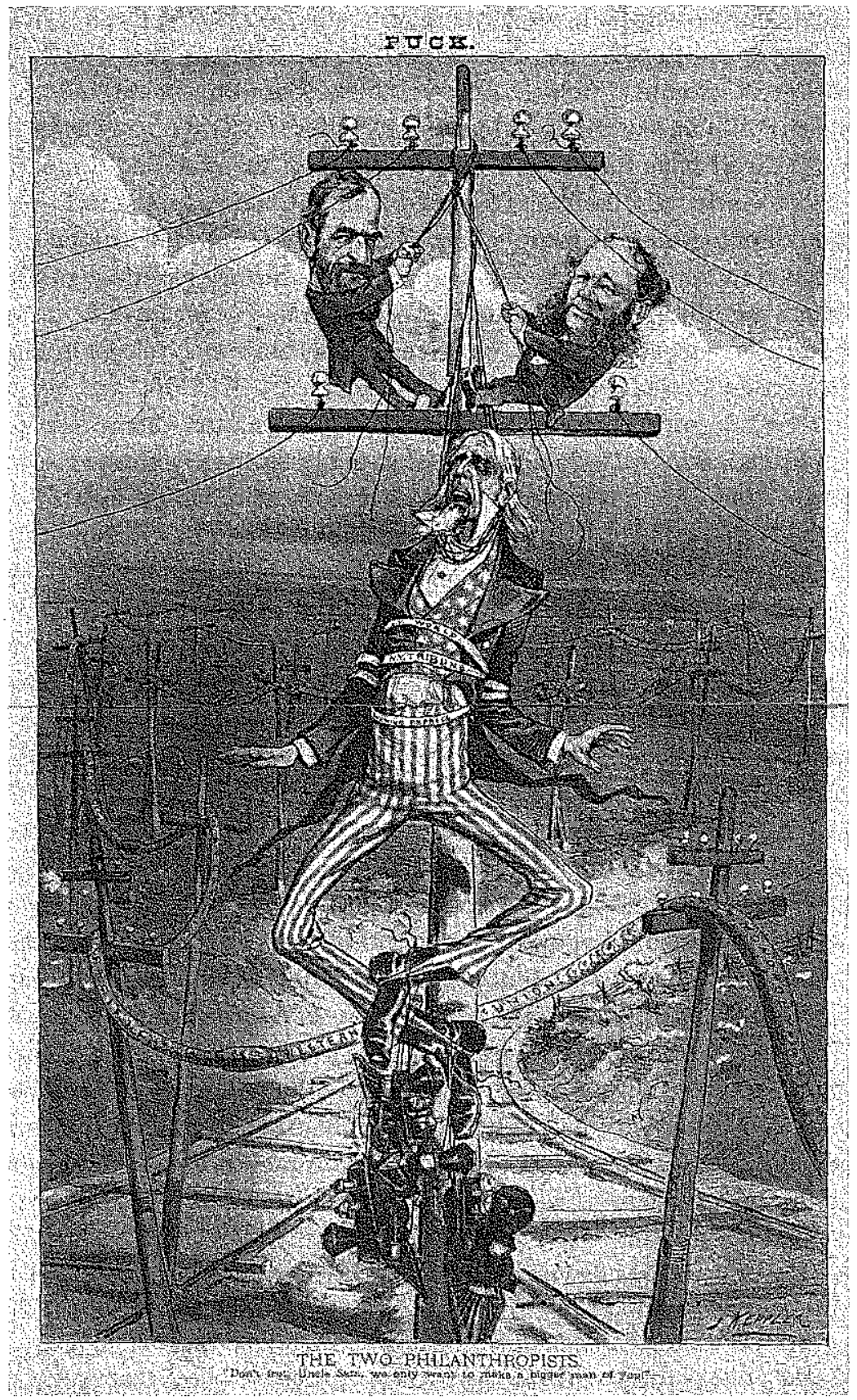

Figure 4 For Puck cartoonist Joseph Keppler, Jay Gould and William H. Vanderbilt were favorite subjects. In this evocative cartoon, they were ridiculed as phony "philarithropists" determined to use their control over Western Union to strangle Uncle Sam. Joseph Keppler, "The Two Philanthropists," Puck 8 (February 23,1881 ): centerfold. 
not only Westem Union and many railroads but also the three NYAP newspapers, the Tribune, the World, and the Express, that they had wrapped around Uncle Sam's waist. Puck's editor identified the telegraph pole as a medieval torture rack; a culturally literate viewer might well have interpreted it as the cross of the crucified Christ. ${ }^{32}$ This was in all likelihood Keppler's intent. Born in Vienna in a Catholic household, Keppler received in his youth a rigorous art education that included a thorough study of history painting, giving him a familiarity with Catholic religious imagery that would have been unusual at this time for a cartoonist born and raised in the Protestant United States. ${ }^{33}$

The magnitude of Gould's perfidy furnished the theme for an ominous cartoon by James A. Wales that ran shortly thereafter in Judge. Here Gould is paired not with Vanderbilt, but with Cyrus Field, a wealthy merchant who had recently purchased an ownership stake in a fourth New York City newspaper, the Evening Express. Working as saboteurs under cover of moonlight, Gould and Field schemed together to disassemble, brick by brick, the "free press lighthouse" that was guarding the channel of "legitimate trade." Each brick bore the name of a newspaper: so long as the bricks remained in place, the press would remain free. Ominously, however, the bricks that Gould. and Field had already dislodged represented four of the seven NYAP newspapers: two owned by Gould, namely; the Tribune and the World, and two owned by Field, namely, the Evening Express and the Evening Mail. ${ }^{34}$ Were the saboteurs not stopped, the outcome was unavoidable: Gould would gain control of the NYAP, threatening the freedom of the press. "Monopoly," Wales declaimed, in explicating his cartoon, was "fast becoming the octopus of American newspapers." To eliminate the danger, it was no longer sufficient to enact legislation to embolden new entrants to challenge the incumbent network provider, the traditional antimonopoly remedy. Instead, lawmakers should enact legislation to graft the telegraph onto the mail and put both under the control of the federal governmént:

The Judge scents danger in a network of wires that can be made to obey the mandates of a single owner. Intelligence can be garbled, delayed, and refused for the benefit of one man's pocket. Yet, to-day, the press of this country is absolutely powerless to check that man's will. The telegraph should be part and parcel of mail system, and

32. Joseph Keppler, "The Two Philanthropists," 'Puck 8 (February 23, 1881): centerfold.

33. West, Satire on Stone, chap. 1.

34. James A. Wales, "The Press in Danger: Monopolists Undermining the Peoples Light-House," Judge 1 (December 10, 1881): centerfold. 
both be under the control of Government. The people demand the news, and should demand the means of its transmission .... We can permit no.juggling with the electric girdle of commerce. We must feel assured that all is not Gould that glistens in print. ${ }^{35}$

Gould's designs on the NYAP inspired a related cartoon by Puck's Frederick B. Opper. How would the New York City newspaper press operate, Opper wondered; were Gould to prevail? Opper's cartoon provided the answer. Gould the newspaper deliveryman sat in the back of a horse-drawn wagon whose driver held reins made of telegraph wires, dictating the news to the editors of the city's leading newspapers, whose identities would have been instantly recognizable to discerning readers. The only editor to remain aloof was Puck's cherubic mascot, who defiantly' stood guard at his non-NYAP "independent" newsstand, which proudly proclaimed "no monopolists need apply." 36

Even gifted cartoonists sometimes got things wrong, and, as it happens, Wales and Opper were mistaken about Gould. During the very same months when they-along with many other journalists, business leaders, and public figures-assumed that Gould was poised to take over the NYAP, Gould was in fact secretly maneuvering behind-the-scenes to build up NYAP's archrival, the Western Associated Press (WAP). Gould's gambit would soon lead to the NYAP's collapse and the reorganization of the WAP as the present day AP ${ }^{37}$ None of this, however, was widely known. Gould's machinations fooled so many in large part because of the cultural context in which they occurred. The antimonopoly critique had by the early 1880 s become so well-known that it seemed almost inevitable that Gould would conspire to gain a stranglehold over the news business by virtue of his holdings in Western Union and the New York City newspaper press.

Gould's ability to manipulate the news was so absolute that he had no need to speculate, or so implied an 1886 Judge cartoon by Grant $\mathrm{E}$. Hamilton (figure 5). The title of Hamilton's cartoon-“'I Never Speculate"'-was a quotation from a celebrated public statement of Gould's. How, Hamilton asked, could Gould venture such an audacious claim? His cartoon provided the answer. Now that Gould had gained control of Western Union and the press, he had unparalleled access to inside information on market trends, an asset

35. James A. Wales, "Peril of the Press," Judge 1 (December 10, 1881), 2.

36. Frederick B. Opper, "When Jay Gould Owns the Associated Press-Puck Will Still Keep His Independent News-Stand," Puck 12 (October 4, 1882): back cover.

37. John, Network Nation, 191-2. 




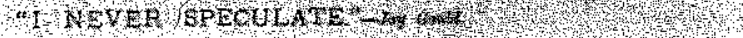

Figure 5 William $\mathrm{H}$. Vanderbilt's death in 1885 opened the way for Jay Gould to assume the throne as "king of Wall Street," according to Judge cartoonist Grant E. Hamilton. Gould's throne, appropriately enough, was a telegraph stock ticker, upon which Gould contentedly sat, writing the stock quotations himself. Grant E. Hamilton, "I Never Speculate'-Jay Gould," Judge 9 (January 9, 1886): back cover. 
that Hamilton ingeniously conveyed by portraying Gould as the "King of Wall Street" whose throne was the telegraph ticker (a machine for printing out stock prices), upon which Gould sat contently, writing the stock prices himself. ${ }^{38}$

Cartoonists typically portrayed Gould in human form--whether it be a child, telegraph lineman, newspaper deliveryman, or monarchan understandable decision in an age when the individual proprietor remained a culture hero. ${ }^{39}$ Yet not always. Sometimes, for example, he was transformed into an animal: a predatory whale; a venomous python; a mischievous raccoon; or even a poisonous tarantula spider whose web, fashioned with telegraph wires, had ensnared the courts. ${ }^{40}$

These cartoons underscored a dimension of Gould's audacity that has often eluded historians and that was the extent to which Gould's financial wizardry imperiled the commercial world. For the readers of Puck and Judge, Gould was not a Schumpeterian agent of creative destruction, but merely an agent of destruction--a "wrecker" as he was often called in the press. Two cartoons help make this point. The first characterized stock trading on Wall Street as a "Cut-Throat Business" in which Gould and Vanderbilt had the power, by virtue of their inside access to information on market trends, to slit the throats of the many investors foolish enough to speculate in the shares of highly leveraged corporations like Western Union (figure 6). ${ }^{41}$ In the second, New York City's stock exchange became "Hell-Gate," a notoriously dangerous, stretch of the East River in the city's harbor. Looking down at the churning waters was Gould, now the figurehead on a harp labeled "speculation" that had been strung with ticker tape listing the prices of unusually risky stocks that including Western Union. Plucking the harp strings was the siren of speculation, a classical temptress, luring unwary investors to their doom. To reinforce the siren's linkage with Gould, her head was crowned with

38. Grant E. Hamilton, "I Never Speculate'-Jay Gould," Judge 9 (January 9, 1886): back cover. In an editorial accompanying the cartoon, Judge editor James A. Wales explained its significance: "When the present King of Wall Street, by lineal succession to [William H.] Vanderbilt, dec'd, said 'I never speculate,' he toid a frank and literal truth. He leaves others to speculate on what is to him certainty. He is willing they should take all the chances and have all the fun and excitement, modestly contenting himself with raking in the pot." "The Man in the Ticker," Judge 9 (January 9, 1886), 2.

39. Laird, Advertising American Progress, esp, chap. 2.

40. Joseph Keppler, "The Monster Monopoly," Puck 10 (January 25, 1882): centerfold; Frederick Graetz, "The Anaconda at a Loss," Puck 14 (October 31, 1883), 131; T. Bernhard Gillam, "A New Version of an Old Story," Puck 13 (August 22, 1888): back cover; Frederick B. Opper, "Justice in the Web," Puck 17 (July 22, 1885); front cover.

41. Joseph Keppler, "Cut-Throat Business in Wall Street-How the Inexperienced Lose Their Heads," Puck 10 (September 7, 1881): centerfold. 


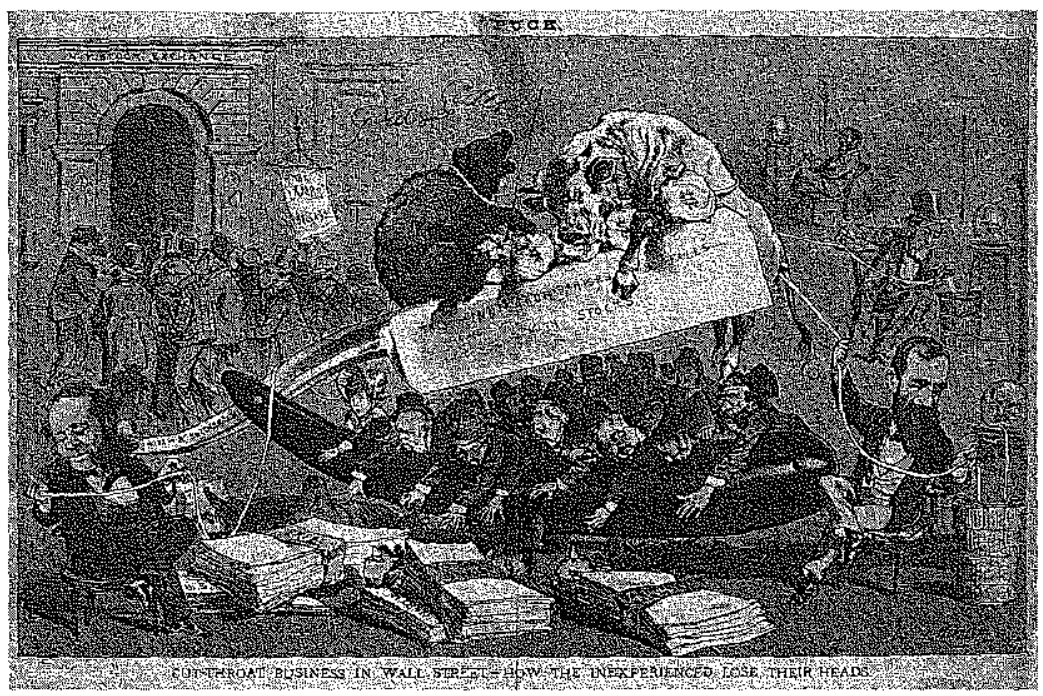

Figure 6 Few business practices provided more satirical fodder for cartoonists at Puck and Judge than the ingenuity with which financial insiders like Gould and Vanderbilt bamboozled unwary investors. To remind his audience that Wall Street was a "cut-throat business," cartoonist Joseph Keppler portrayed Gould and Vanderbilt as barbers slitting the throats of their naive customers. Joseph Keppler, "Cut-Throat Business in. Wall Street-How the Inexperienced Lose their Heads, "Puck 10 (September 7, 1881): centerfold.

a tiara fashioned out of telegraph poles. The cartoonist's point was plain: just as New York City's Hell-Gate imperíled commerce, so, too, did speculation. "Measures Ought to Be Taken at Once," the caption urged, in reference to the sharp trading in which speculators like Gould engaged, "to Blow up this Obstruction to Legitimate Trade" (figure 7). ${ }^{42}$ Notwithstanding the magnitude of the evil, neither Puck nor Judge had much confidence anything would be done. Now that Gould the farmer had "bagged" Western Union, or so a Judge cartoon from 1885 opined, he would remain in business until the last remaining gullible Wall Street investor, or "lamb," had been fleeced.43

Gould's biographer Maury Klein dismissed the antimonopoly critique as the pathetic whining of the losers of a high stakes faro game at which Gould excelled. ${ }^{44}$ Louis Galambos, similarly, has

42. Frederick Graetz, "The Wall Street Hell-Gate: Matters Ought to Be Taken at Once to Blow Up This Obstruction to Legitimate Trade," Puck 15:(May 14, 1884): back cover.

43. D. Mac, "Jay Gould Is Going to Retire Permanently from Wall Street'Daily Paper. Yes; When He Has Finished this Job, and Not Before-The Judge," Judge 9 (December 26, 1885): front cover.

44. Klein, Life and Legend of Jay Gould, esp. chap. 23. Oddly, Klein reprinted a sheaf of Puck anti-Gould cartoons in his magisterial biography of Gould without commenting on them in the text (following 374). 


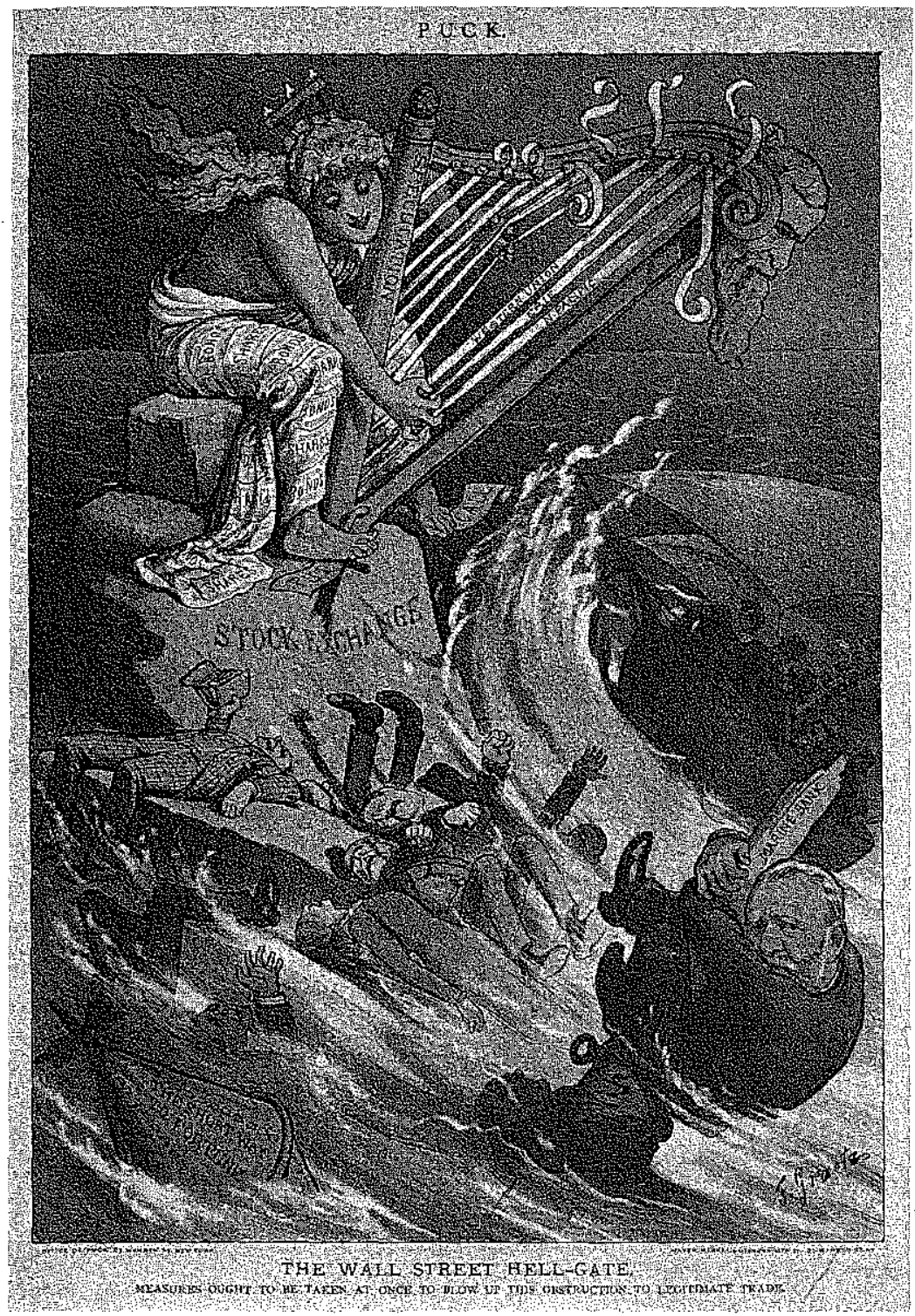

Figure 7 The presumption that financial speculation was an impediment to commerce was widely shared in the 1880 s by merchants, journalists, and lawmakers. In this cartoon, the stock exchange is depicted as a rock outcropping upon which the siren of speculation lured gullible investors to their ruin. Mounted on the siren's harp was a bust of the consummate speculator Jay Gould. Frederick Graetz, "The Wall Street Hell-Gate: Measures Ought to Be Taken at Once to Blow Up This Obstruction to Legitimate Trade," Puck 15 (May 14, 1884): back cover. 
implied that it demonstrated a lingering uneasiness with an "organizational revolution" that in 1880 had just recently begun. ${ }^{45}$ Neither of these explanations fully explained the cartoonists' concern. The cartoonists' ultimate target was neither sharp trading nor giant organizations, but, rather the political economy that emboldened speculators like Gould. Gould's ascendancy at Western Union demolished the fallacy that antimonopoly legislation could be counted on to encourage new entrants to challenge incumbents. The cartoonists' assumed not only that their audience understood thishad they not it would have been pointless to make Gould's business practices an object of satire--but also that it was time to cast the net widely for solutions.

What was to be done? Ever more stringent antimonopoly legislation, commission regulation, and government ownership all had their champions. For the cartoonists at Puck and Judge, the primary alternatives were antimonopoly legislation and government ownership. "The Best Remedy" was additional antimonopoly legislation, opined James A. Wales in February 1881, one month after Gould's takeover of Western Union, in one of the last cartoons he drew for Puck before he moved over to Judge. Should Congress charter an "anti-monopoly" telegraph company, the "Consolidated Extortion Telegraph Company" would be doomed. ${ }^{46}$ Antimonopoly legislation, however, had its own subtle perils, as a perceptive Puck cartoon that ran eight months later made plain (figure 8). When confronted with roads pointing in two directions, one toward "Monopolyville" and the other to "Anti-Monopolyville," the magazine's mascot was perplexed. The reason was simple. Though the former road led to Gould's "Monopoly Telegraph Co.,". the latter led to John Kelly's Tammany Hall, New York City's notorious Democratic political machine. "Well, I want to be an anti-monopolist," Puck's mascot reflected thoughtfully, but not if it led him into Kelly's clutches. "Down with the bloated monopolists!!," proclaimed a banner that Kelly held aloft, in endorsing new antimonopoly legislation. Kelly, however, was in the Puck cartoonist's eyes not being sincere: Kelly opposed monopoly not becau'se he objected to morally questionable business practices but, rather, because he recognized in the antimonopoly groundswell a golden opportunity for political

45. Galambos, Public Image of Big Business, esp. chap. 9. Published one year before Chandler's Visible Hand, and written in a similar spirit, Galambos's Public Image can be read as a social-scientific debunking of the robber baron epithet. Galambos's source base consisted mostly of popular magazines, which he analyzed using the then-fashionable, yet since largely abandoned-at least among historians-method of content analysis.

46. James A. Wales, "The Best Remedy," Puck 8 (February 2, 1881): front cover. 


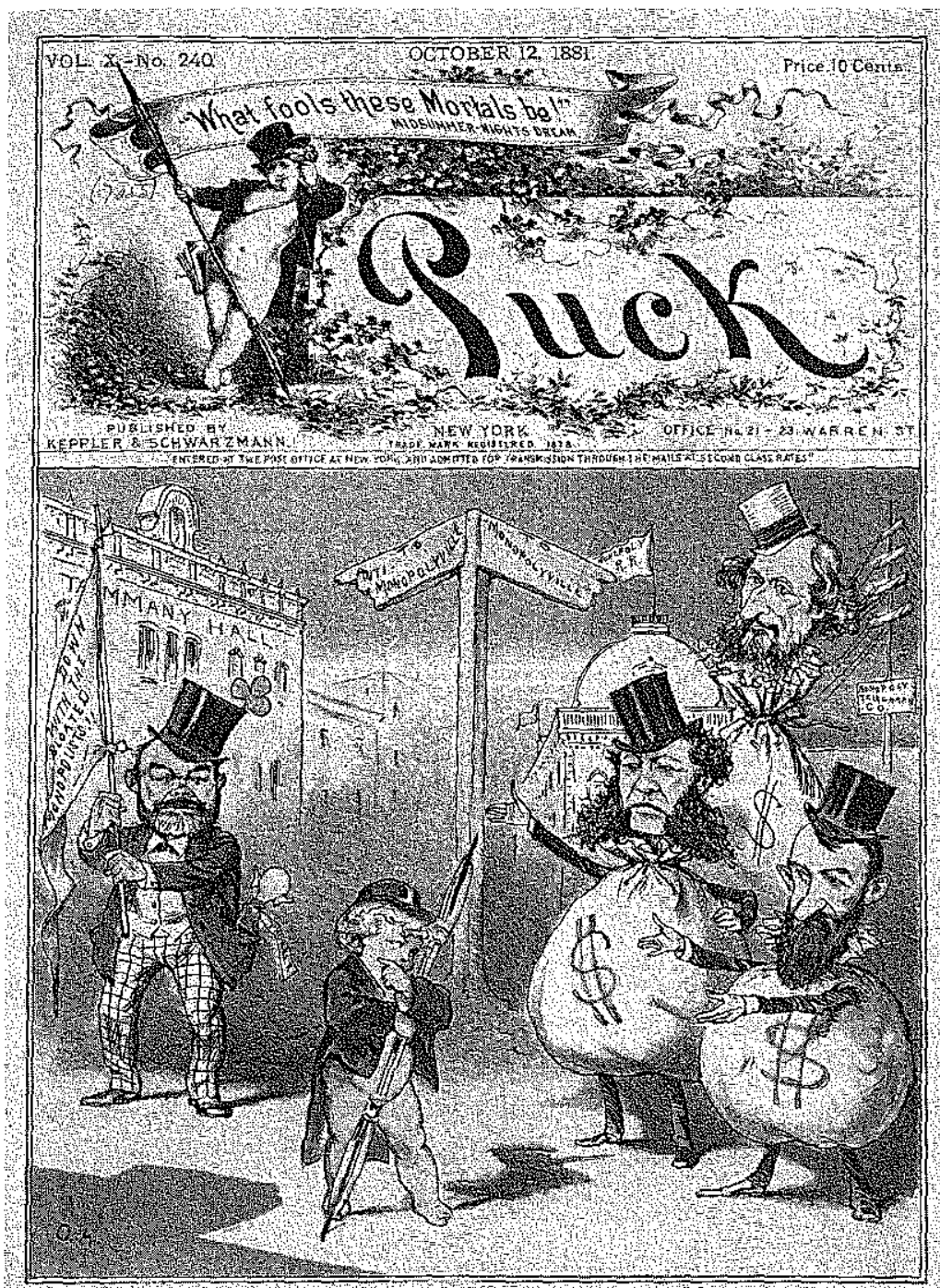

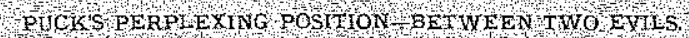

G.

Figure 8 Gould's takeover of Western Union in 1881 prompted many calls for federal legislation to restrain Western Union. The enactment of antimonopoly legislation had many supporters, yet, or so this Puck cartoonist warned, its legitimate backers were easily co-opted by New York City's notorious political machine. O. K., "Puck's Perplexing Position--Between Two Evils," Puck 10 (October 12, 1881): front cover.

aggrandizement or even outright graft. Should lawmakers float an antimonopoly bill, for example, Kelly hoped to get some of the credit, or even a hefty payout from Gould to ensure that it was never enacted. Under the circumstances, the enactment of additional antimonopoly 
legislation might well cause more harm than good. To make this point, the cartoonist included a telling detail. Among Kelly's unwitting accomplices, or so the cartoonist implied, was the wealthy dry goods merchant Francis B. Thurber, who, notwithstanding the good intentions of Thurber's recently established "Anti-Monopoly League," was quite literally in Kelly's back pocket. ${ }^{47}$

Neither Puck nor Judge placed much faith in commission regulation, presumably because they feared it would foster corruption. With antimonopoly legislation increasingly discredited, this left government ownership, a remedy that cartoonists at both magazines briefly endorsed. ${ }^{48}$ Government ownership today is typically regarded as the antithesis of antimonopoly. In the 1880s, however, it was often its complement. This was particularly true for those contemporaries with even a passing familiarity with John Stuart Mill's Principles of Political Economy, first published in 1848. For Mill and his American acolytes, government ownership was a logical policy response to economic consolidation in a business sector in which the possibility that insurgents might challenge incumbents had for some reason been foreclosed. ${ }^{49}$ Wales, now at Judge, showed why. "The Best Kind of Monopoly," Wales proposed, was a telegraph network owned and operated by the Post Office Department as a government agency (figure 9). Such a network, Wales predicted, would isolate "wrecker monopolists" like Gould behind the rivers of watered stock with which they had flooded the market. The caption to Wales's cartoon underscored his confidence in government ownership as a remedy for the perilous situation that had been occasioned by Gould's stranglehold over the means of communication; "Let the People's Government Supply the People's Information:"50

47. O. K., "Puck's Perplexing Position--Between Two Evils," Puck 10 (October 12, 1881): front cover. In an accompanying comment, Puck's editor explained the rationale for this cartoon: "Mr. Kelly is a champion of the Anti-Monopoly cause just as the vendor of 'buchu' patent medicines is a benefactor to the human racebecause it pays him .... It has struck him that there was something to be done in a 'deal' with that pseudo-organization which calls itself the Anti-Monopoly party .... If he had been a first-class statesman, he would have seen that the movement against the tyranny of misused capital has not yet reached-sufficient proportions to make it a tool for even the most skillful of politicians. As things stand, he has only weighted his own party with the responsibility of an issue of, as yet, doubtful popularity, and has discredited the good faith of many honest and disinterested reformers" (82).

48. Puck 8 (February 2, 1881), 362; James A. Wales, "Peril of the Press," Judge 1 (December 10, 1881), 2.

49. Mill, Principles of Political Economy 2, 540.

50. James A. Wales, "The Best Kind of Monopoly," Judge 2 (October 7, 1882): front cover. 

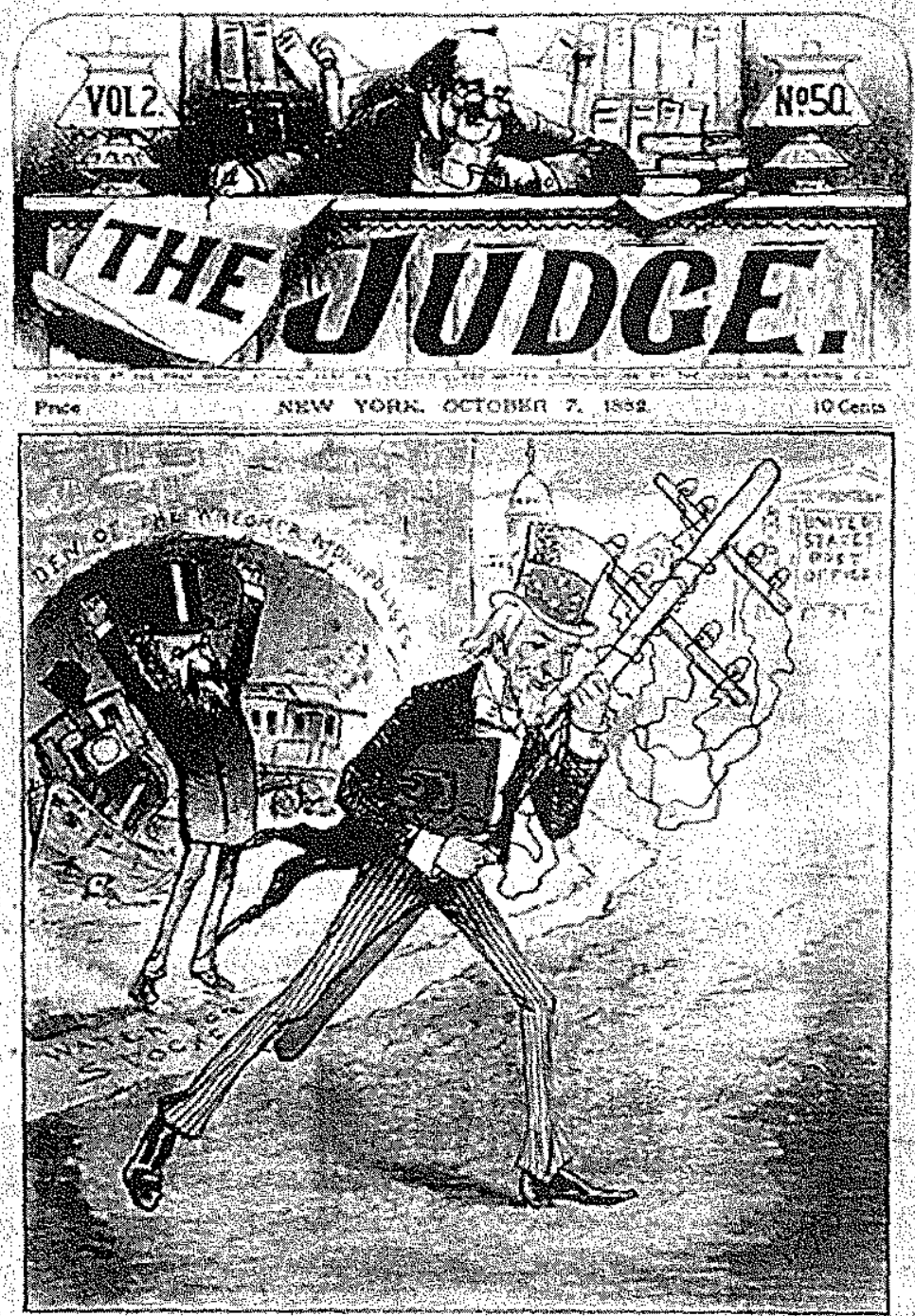

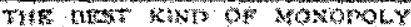

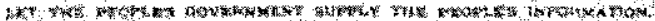

Figure 9 The "best kind of monopoly," according to Judge cartoonist James A. Wales, was a monopoly like the Post Office Department owned and operated by the federal government: "Let the People's Government Supply the People's Information." James A. Wales, "The Best Kind of Monopoly," Judge 2 (October $7,1882)$ : front cover.

The political message of Wales's cartoon challenges present-day assumptions regarding big government and big business. Today, it is a commonplace to criticize the federal government for incompetence, mismanagement, and fraud. Had Wales wished to ridicule the Post 
Office Department for its administrative failings, he had no shortage of material. The Post Office Department in 1882 was reeling from a cascading series of embarrassing disclosures that implicated highranking postal administrators in a massive contracting scandal, the socalled "star route" frauds. The star route scandal received wide publicity in the press and did not go unremarked in Judge..$^{51}$ Interestingly, however, neither Wales nor anyone else at either Judge or Puck held it up as proof that the Post Office Department was ill-equipped to operate the telegraph as well as the mail. From a joumalistic standpoint, this was unsurprising. Strange as it might seem, journalists from across the political spectrum regarded the administration of the Post Office Department as a public agency as superior to the management of Western Union as a private corporation, while a few even praised the Post Office Department as more technically advanced..$^{52}$ Even the oft-voiced complaint that the Post Office Department was a sinkhole of party patronage was beginning to wear thin: with the recent enactment of civil service legislation, it seemed plausible to assume that the promise of a nonpartisan civil service was about to be realized. Journalists extravagantly praised the recent establishment by the Post Office Department of a high-speed "Fast Mail" rail link between New York City and Chicago, even if, or perhaps more accurately, precisely because, it obliged postal administrators to jawbone railroad leaders like William H. Vanderbilt to subordinate their private interest as investors to the needs of postal patrons by adjusting their schedules to speed the mail. ${ }^{53}$

Among the government administrators who coordinated the Fast Mail was an ambitious young civil servant named Theodore N. Vail. For Vail, the robber baron was more than a mere journalistic abstraction: During Vail's tenure in the Post Office Department, he had found himself embroiled in a nasty quarrel with Vanderbilt over postal scheduling on the New York City-Chicago route that culminated with Vanderbilt's audacious decision to throw the mail off his trains. It was in response to a journalist who asked Vanderbilt to explain why he had flaunted public authority that Vanderbilt snarled "the public be damned." "54 It was a lesson Vail never forgot. Many years later, as president of the country's dominant telephone network provider Vail would invert Vanderbilt's priorities. The telephone corporation Vail headed up was American Telephone and Telegraph, the successor to

51. "The Star Routers' Ascent: Slowly but Surely Approaching Justice," Judge 1 (March 4, 1882): front cover; "The Downfall of a Great Statesman: Dorsey in the Hands of Justice," Judge 1 (April 22, 1882): front cover.

52. John, Network Nation, 182-3.

53. John, Network Nation, 214-15.

54. John, Network Nation, 214-15. 
American Bell, and, like American Bell, popularly known simply as Bell. Instead of regarding his investors' financial return as his highest priority, as Vanderbilt had, Vail proclaimed that his primary obligation as corporation president was to promote the public good. Vail was by no means being purely altruistic. By wrapping himself in the flag, Vail shielded Bell from hostile legislation. Even so, Vail's public stance was alien to a Vanderbilt or a Gould, and underscored the yawning chasm that separated the manager-oriented progressive political economy in which Vail rose to power from the investor-oriented antimonopoly political economy in which Vanderbilt and Gould had thrived.

The most serious danger posed by government owmership of the telegraph network was not theoretical but practical. Had Congress established a government telegraph monopoly, it would have been obliged under the National Telegraph Act to buy out the existing network providers, including Western Union's largest investor, Jay Gould. The dilemma lawmakers confronted was nicely revealed in 1888 by a Puck cartoon that depicted Gould as a wily raccoon who had scrambled up a tree to avoid a potentially unpleasant encounter with a gun-wielding Uncle Sam-imaginatively decked out in the garb of the iconic frontiersman Davy Crockett (figure 10). Ever resourceful, Gould informed the frontiersman that he would happily sell Western Union to Congress-which, in fact, was true-should Congress pay him $\$ 80$ million, an exorbitant sùm that was more than four times what the best-informed business analysts assumed Western Union to be worth. Gould's offer was outrageous, the cartoonist made plain, because the value of the assets that Gould had agreed to sell had been enormously inflated by Gould himself. ${ }^{55}$

The heuristic that Gould used to value Western Union's assets testified to his ingenuity. Gould based the value of Western Union's shares on the financial return it could generate for its investors, which he termed their future earnings power. This future-oriented heuristic is commonplace today; stocks are presumed to be worth whatever investors will pay for them. In the $1880 \mathrm{~s}$, however, it was anathema. Gould's overvaluation of Western Union's 'shares, critics charged, obliged him to pay out to investors an excessive amount of revenue in dividends, making inevitable the overcharging of users, the underpayment of workers, and the underinvestment in new technical contrivances. Financially innovative, Gould's Western Union was technically retrograde, a conclusion reached not only by the cartoonists at Puck and Judge but also by journalists familiar with the telegraph networks of Great Britain and Germany. ${ }^{56}$

55. T. Bernhard Gillam, "A New Version of an Old Story," Puck 13 (August 22, 1888): back cover.

56. John, Network Nation, 182-3. 


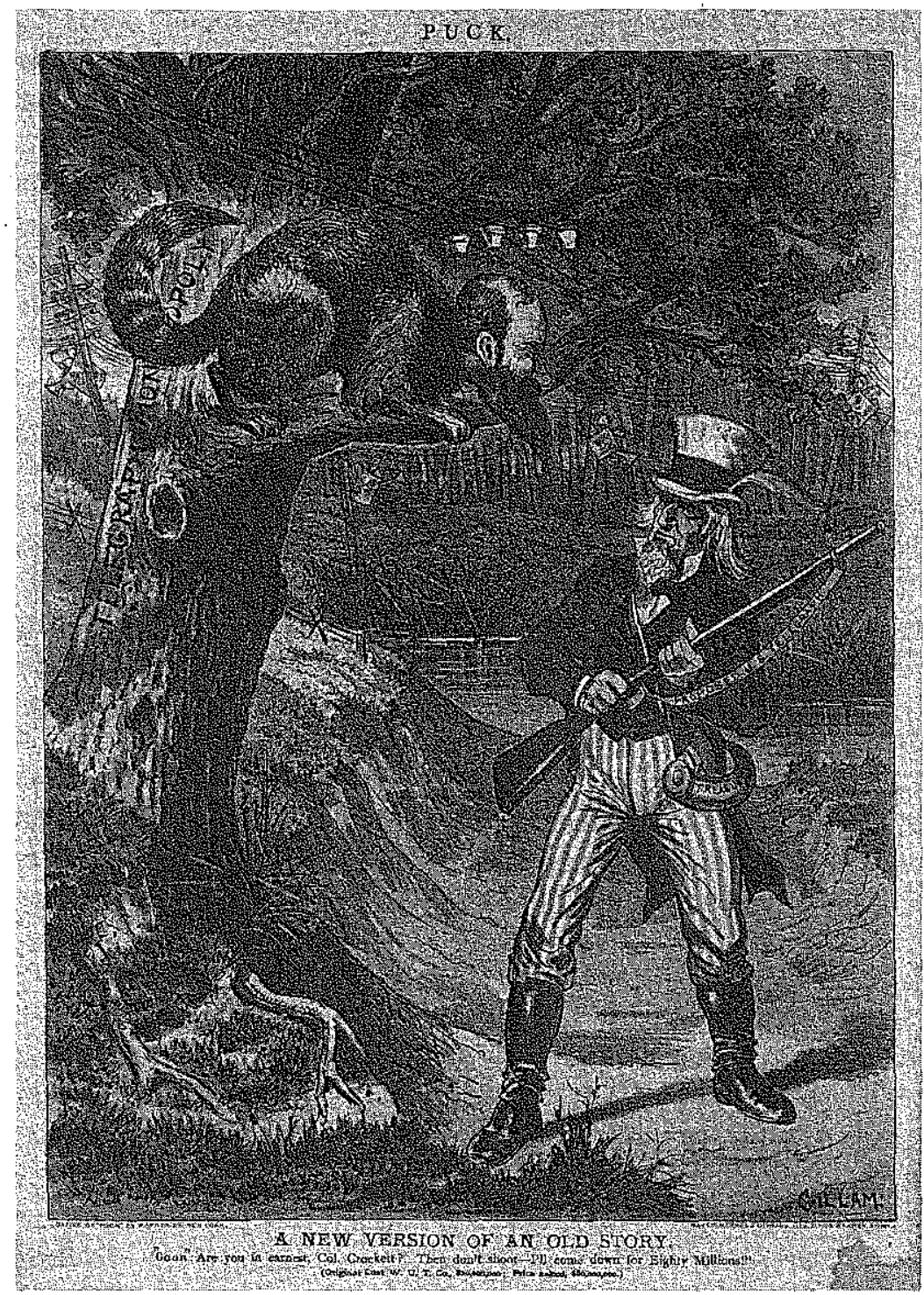

Figure 10 Opposition to a federal takeover of the telegraph network in the $1880 \mathrm{~s}$ focused less on the relative merits of government administration and corporate management than on the financial windfall that a congressional buyout would lavish on speculator Jay Gould. In this Puck 'cartoon, Gould is depicted as a wily raccoon poised to outsmart Uncle Sam, who is fitted out as the iconic frontiersman Davy Crockett. If Congress wished to purchase Western Union for an outrageous sum, Gould informed the frontiersman, he had no objection to the sale. T. Bernhard Gillam, "A New Version of an Old Story," Puck 13 (August 22, 1888): back cover.

Gould's Western Union in the 1880 s was in no sense a "natural monopoly," as historians often contend, following business historian Robert Luther Thompson, who posited that the trend toward 
monopoly in the telegraph business had become "irresistible" by 1866. ${ }^{57}$ Rather, it exploited a loophole in the antimonopoly political economy to forestall new entrants by negotiating exclusive right-ofway agreements with the country's leading railroads. Had the courts challenged these agreements, Western Union would have been unable to maintain its dominant position. Yet, with a few notable exceptions, the courts demurred, unwilling to challenge the sanctity of contracts, even if, or perhaps because, they safeguarded Western Union's prerogatives.

The antimonopoly critique had different implications in the telephone business. Here, too, politics had artifacts: in the telephone business, as in the telegraph business, the business strategy of network providers was shaped by the structuring presence of the state. ${ }^{58}$ Yet the political economy in which telephone companies operated was quite different from the political economy in which Western Union had triumphed. Telephone operating companies were not chartered, as Western Union had been, under antimonopoly laws intended to

57. Thompson, Wiring a Continent, 440. Thompson inherited from his Ph.D. advisor, Allan Nevins, a functionalist view of corporate combines like Western Union. In Visible Hand, Chandler echoed Thompson's misleading characterization of the telegraph giant. So too, in the main, did media scholar James W. Carey in an oft-cited essay on "Technology and Ideology: The Case of the Telegraph" (Carey, Communication as Culture, 155-77). For more on Carey, see John, "Commumications Networks." For a rare pre-2010 objection to Chandlerian orthodoxy on Western Union, see Du Boff and Herman, "Alfred Chandler's New Business History."

58. Winner, "Do Artifacts Have Politics"; Dunlavy, Politics and Industrialization, 4. The idea that the state might in certain circumstances be an independent agent of change-as opposed to, say, the instrumentality of a social class-was much discussed in the 1980s by graduate students at Harvard and MT in history, sociology, and political science. At the time, it was widely assumed that society, and not the state, was the proper subject of analysis, an assumption shared by business historians, social historians, and many historical sociologists. I first encountered what we then called state-centered social theory in Theda Skocpol's "Bringing the State Back In." Intrigued by Skocpol's research agenda, I presented in 1990 a paper based on my dissertation for Skocpol's famed Committee on Social and Political Organization. In the following years, I published several essays and one edited book that were intended to introduce historians to this theoretical tradition. Among these essays were "Governmental Institutions"; "Farewell to the "Party Period",; "Ruling Passions"; and "Telecommunications." "Ruling Passions" was the introduction to a collection of original essays that I edited for the Journal of Policy History, and which was issued shortly thereafter in book form.

Like myself, Dunlavy was a graduate student in the 1980s, and, like myself, she was simultaneously influenced by and critical of Chandler. Dunlavy used the felicitous phrase "structuring presence" to characterize state structures in her influential monograph on comparative nineteenth-century industrialization in the United States and Prussia. In the years since, I have tried to keep both the phrase and its association with Dunlavy's monograph afloat. Dunlavy, Politics and Industrialization, 4; John, "Elaborations, Revisions, Dissents," 184; John, "Governmental Institutions," 377. 
discipline incumbents and encourage new entrants. Rather, they were municipal franchise corporations tightly regulated by city councils: entry, rates, and performance standards were determined by political fiat rather than market competition.

Telephone operating companies in the 1880s were highly unpopular with their users, the vast majority of whom were businessmen. High rates and low performance standards were the primary grievances: why, users demanded, were investors being enriched at their expense? Hostility became especially intense when, in 1888 , the Supreme Court legitimated the patent rights that the patent office had earlier granted to telephone inventor Alexander Graham Bell. These patent rights were owned by American Bell, the holding company that licensed exchanges in the nation's major urban centers, including New York City. User disscontent was dramatized in a hard-hitting cartoon 1888 by Judge cartoonist Grant E. Hamilton in which Hamilton depicted American Bell as a rapacious spider that has trapped in its web not only the federal government but also its users: brokers, bankers, and druggists. How did American Bell prevail? Not through superior management, but, rather, though a variety of dubious strategems that included, as the spider's tentacles proclaimed, "treachery," "corruption," and "undue influence." 59

No Puck or Judge cartoonist in the 1880s championed open entry for new telephone operating companies as a remedy for high rates, low performance standards, and overly generous dividend payments. If anything, they regarded competition as a' menace. Consider, for example, the response of Judge cartoonists to the proliferation of overhead wires that had been hastened by the rapid expansion of the telephone business in New York City. Early in the decade, cartoonists struck a light-hearted note. In one cartoon, for example, overhead wires helped a peddler display his wares and an apartment dweller dry her laundry. ${ }^{60}$ In another, a futuristic fantasy set "five hundred years hence," overhead wires strung by telephone and telegraph companies looped over the outstretched arm of the Statue of Liberty. ${ }^{61}$ When it became widely known that the entanglement of low-voltage telephone and telegraph wires with high-voltage electric power wires threatened passersby with electrocution, the tone changed. Some cartoonists played this potentially lethal hazard for laughs. In one

59. Grant E. Hamilton, "In the Clutch of a Grasping Monopoly," Judge 14 (April 7,1888 ): back cover.

60. Eugene Zimmerman, "High Time Something Was Done About It," Judge 10 (August 14, 1886): back cover.

61. Grant E. Hamilton, "A Peep into the Future," Judge 11 (October 30, 1886): back cover. 
whimsical cartoon, street goers, their horses, and even their dogs protected themselves against electrocution by donning Judge's patented "Non-Conductor Rubber Suits." 62 For others, the situation had become tragic. In one arresting cartoon inspired by an actual news story, the supposedly, beneficent electric light bulb had been transmogrified into a skull that hovered ominously over the dangling corpse of a telegraph lineman whose electrocuted body had become enmeshed in overhead wires. ${ }^{63}$

Competition briefly flourished in the telephone business for a few years in the 1890s and 1900s following the expiration of the second of Alexander Graham Bell's patents in 1894. Even here, however, the business strategy of telephone operating companies remained constrained by the political economy of the municipal franchise corporation. In the telephone business, competition was always contrived. The exception that proved the rule was the 1913 settlement that the federal justice department brokered with Bell and its rivals to forestall the prosecution of Bell under the Sherman Act for restraining trade. With this settlement, according to one wit, the "telephone trust" had been "disconnected." 64 The reality was more complicated. The settlement was in no sense a victory for competition: no lawmaker seriously proposed the enactment of legislation to encourage new entrants to contest the market. Instead, lawmakers segmented the market to facilitate its orderly regulation. In return for certain concessions, the existing network providers-that is, Bell and its non-Bell, or "independent," rivals--were guaranteed a steady financial return. This ruling shielded Bell from legal assault, a nontrivial benefit in a highly uncertain political environment. More importantly, it was a godsend for the independents, since it assured wary investors that the independents would, in fact, survive, and, thus, that they could prudently loan them the capital that many desperately needed to remain afloat.

Bell would remain the dominant telephone network provider in the United States from 1913 until the court-ordered breakup of the Bell System in 1984. Under the leadership of President Theodore N. Vail, who had not forgotten his earlier quarrel with William $\mathrm{H}$. Vanderbilt, Bell came to justify its dominant position by ostentatiously proclaiming the subordination of merely economic considerationsincluding, in particular, the maximization of its investors' financial return-to loftier goals such as technical innovation and the

64. "Disconnected, B'Gosh!" Portland Oregon Journal, Juy 26, 1913. 
provisioning of low-cost local telephone service to the entire population. The capitalization of Bell securities, Vail decreed, was to be based not on future earning power, but on sunk costs-with no allowance for franchise values or good will. In so doing, Vail rejected the future-oriented financial heuristic that Gould had pioneered.

Henceforth, Bell combined financial orthodoxy with technical virtuosity, a business strategy aptly symbolized by the completion in 1915 of its money losing, but reputation enhancing, transcontinental telephone hookup, an achievement made possible by the first commercial application of the high-vacuum tube, an innovation that historians of science credit with marking the advent of electronics. To burnish Bell's image for technical virtuosity, corporate publicists touted the transcontinental telephone line as a "Triumph of Science," an ostensibly apolitical ideal that concealed Bell's indebtedness to the political economy in which it flourished and for which its business strategy had been designed. ${ }^{65}$

To characterize the 1880 s as a "gilded" age is misleading. In few decades was public revulsion at financial speculation more pointed. ${ }^{66}$ The "gilded age" catch phrase was almostnever used by contemporaries to characterize the epoch and would not be popularized until after the First World War; to this day, it remains the only commonly accepted periodizing device in US historiography that is explicitly pejorative. Even so, the years between 1900 and 1917 can be properly called progressive. This epoch witnessed the chastening of investordominated combines like Gould's Western Union and the ascendancy of technically oriented, public-relations savvy, management-Ied corporations like Vail's Bell.

The revulsion against financial speculation so vividly portrayed in Puck and Judge in the 1880s became a hallmark not only of the managerial corporation but also of the "organizational synthesis" of American business history that Louis Galambos popularized in his pioneering attempt to integrate into American historiography the "managerial revolution" that Chandler had documented in several influential essays, as well as in Strategy and Structure (1962) and The Visible Hand (1977). ${ }^{67}$

One oft-overlooked feature 'of both Strategy and Structure and Visible Hand was their anti-investor bias. For Chandler, managers dominated center stage, while bankers, brokers, and speculators

65. John, Network Nation, chap. 11:

66. John, "Who Were the Gilders?"

67. Galambos, "Organizational Synthesis"; Galambos, "Technology, Political Economy, and Professionalization." 
remained in the wings. The anti-investor bias of the corporate manager was for Chandler a family tradition. Chandler's great-grandfather was the business journalist Henry Varmum Poor, editor of the American Railroad Journal and the Poor of the Standard and Poor credit rating agency. For Chandler, his ancestor's abhorrence toward speculative finance was more than a dimly remembered memory. Poor's business career had been the subject of Chandler's $1952 \mathrm{PbD}$ dissertation, and, as Chandler documented in the book that grew out of this dissertation, Poor had vociferously denounced stock watering as early as 1854. From that year onward, Chandler observed, Poor "continued to deplore the heavy tax placed on American trade by the ever-growing amount of water in American railroad stocks." 68 There is no evidence that Poor himself ever denounced railroad leaders as "robber barons" in the American Railroad Journal or anywhere else. Yet if he had, it would have been entirely consistent with his pointed indictment of speculative finance. .

The visual iconography of antimonopoly that Puck and Judge cartoonists popularized in the 1880 s would long remain a resource for critics of corporate excess. Its legacy was particularly evident in the progressive era, a period in which moral indignation toward giant corporations helped inspire the investigative reporting that is today known as muckraking. Continuities abound. For example, the imperious business magnate that in 1890 a Puck cartoonist had derided as "King Monopoly" would reappear eleven years later in a Puck' caricature of John D. Rockefeller. ${ }^{69}$ The magnate's iconographic descendent lives on today in vestigial form as "Rich Uncle Pennybags," a trademark of the popular board game "Monopoly," itself an heir of the antimonopoly critique of private land ownership that had been popularized by the late-nineteenth-century activist Henry George. ${ }^{70}$ A Judge cartoonist rendered Standard Oil an octopus as early as 1884 , a conceit that a Puck cartoonist would revive in $1904 .{ }^{71}$ The visual iconography with which Keppler savaged dubious drug manufacturers as a patent medicine "trust" in Puck in 1881 would, similarly, find echoes in a Collier's cartoon in 1905. Each depicted the patent medicine business as a menacing skull whose rotting teeth had been fashioned out of the death-dealing bottles that it purveyed. ${ }^{72}$ A second

68. Chandler, Poor, 136; John, "Turner, Beard, Chandler," 234-5.

69. Louis Dalrymple, "And. He Asks for More!" Puck 27 (May 7, 1890): centerfold; John S. Pughe, "The King of the Combinations," Puck 49 (February 27, 1901): centerfold.

70. Orbanes, Monopoly, chap. 1.

71. Frank Beard, "A Giant Monopoly," Judge 6 (July 19, 1884): centerfold; Udo J. Keppler, "Next!" Puck 56 (September 7, 1904): centerfold.

72. Joseph Keppler, "Death's Head-Doctors-Many-Paths to the Grave," Puck 9 (April 3, 1881): centerfold; E. W. Kemble, "Death's Laboratory," Collier's 34 (June 1905): front cover. 
biting Keppler cartoon from 1881, "Bosses of the Senate," anticipated several of the key themes that journalist David Graham Phillips would explore over two decades later in his landmark 1906 muckraking expose, "The Treason of the Senate."73

The presumption that big business posed a greater menace to the republic than big government would remain, at least among cartoonists, conventional until the First World War. Only then would it become common for cartoonists to identify the monster octopus with the state and not the corporation, as would one New York Herald cartoonist in 1919, in opposing the proposed congressional buyout of the telegraph, telephone, railhoad, and cable. ${ }^{74}$

The economic legacy of the antimonopoly critique is harder to assess, but even more consequential. Antimonopoly legislation could foster innovation. The entrepreneurial hothouse in the telegraph business that antimonopoly legislation had spawned in the $1870 \mathrm{~s}$ spurred the invention of three of the most fundamental innovations of the age: namely, the telephone, the phonograph, and the electric power station. And in no sense was this legacy confined to the distant past. Institutionalized at the federal and state level though a welter of laws and regulations that included, but were by no means confined to, state and federal antitrust statutes, antimonopoly remains today a pillar of the American political economy. The Japanese economic mixacle owed something to the imposition of antitrust laws by the United States following Japan's defeat in the Second World War; analogous legislation helped spur Europe's postwar economic revival. ${ }^{75}$ In the realm of intellectual property, the antimonopoly critique remains influential in domains as diverse as patents, copyright, and trademarks; in addition, it continues to provide a compelling rationale for the legally mandated market segmentation of several business sectors, including communications.

It is always risky for a historian to predict the future. Yet it would not be surprising, given the egregious financial abuses of the recent past, if we were to witness in the coming years a revival of the antimonopoly critique that had been in the 1880 s such a prominent feature of public discourse. Contrary to a common assumption, at least among historians, this critique did not take as its target the socalled "organizational revolution," while it owed its inspiration

73. Joseph Keppler, "The Bosses of the Senate," Puck 24 (January 23, 1889): centerfold.

74. "Is This What We Fought For?" New York Herald [1919], reprinted in Review of Reviews 59 (February 1919), 138.

75. Freyer, Antitrust and Global Capitalism; Wells, Antitrust and the Formation of the Postwar World; Berk, Brandeis. 
neither to hidebound reactionaries nor to impractical visionaries. Rather, it drew its principal inspiration from the time-honored, and often well-founded, objections of merchants, lawmakers, and the journalists who championed their cause-including the cartoonists at Puck and Judge-to a political economy in which they could plausibly contend that business leaders lacked accountability, giant corporations favored the private interests of financial insiders over the public good, and speculation clogged the channels of trade.

Bibliography of Works Cited

\section{Books}

Bensel, Richard Franklin. The Political Economy of American Industrialization, 1877-1900. Cambridge: Cambridge University Press, 2000.

Berk, Gerald. Louis D. Brandeis and the Making of Regulated Competition, 1900-1932. Cambridge: Cambridge University Press, 2009.

Bishop, Joseph Bucklin. Oux Political Drama: Conventions, Campaigns, Candidates. New York: Scott-Thaw, 1904.

Carey, James W. Communications as Culture: Essays on Media and Society. Winchester, MA: Unwin Hyman, 1989.

Chandler, Alfred D., Jr. Henry Varnum Poor: Business Analyst, Editor, and Reformer. Cambridge, MA: Harvard University Press, 1956.

- Strategy and Structure: Chapters in the History of the American Industrial Enterprise. Cambridge, MA: MIT Press, 1962.

- The Visible Hand: The Managerial Revolution in American Business. Cambridge, MA: Belknap Press of Harvard University Press, 1977.

Dewey, Donald. The Art of Ill Will: The Story of American Political Cartoons. New York: New York University Press, 2007.

Dorfman, Joseph. The Economic Mind in American Givilization, 1865-1918. New York: Viking Press, 1949.

Dunlavy, Colleen A. Politics and Industrialization: Early Railroads in the United States and Prussia. Princeton, NJ: Princeton University Press, 1994.

Folsom, Burton W., Jr. The Myth of the Robber Barons: A New Look at the Rise of Big Business in America, 3rd ed. Herndon, VA: Young America's Foundation, 1996.

Freyer, Tony A. Antitrust and Global Capitalism, 1930-2004. Cambridge: Cambridge University Press, 2006.

Galambos, Louis. The Public Image of Big Business in America, 1880-1940: A Quantitative Study in Social Change. Baltimore: Johns Hopkins University Press, 1975.

Hess, Stephen, and Sandy Northrop. Drawn and Quartered: A History of American Political Cartoons. Montgomery, AL: Elliot \& Clark, 1997.

John, Richard R. Network Nation: Inventing American Telecommunications.

Cambridge, MA: Belknap Press of Harvard University Press, 2010. 
ed. Ruling Passions: Political Economy in Nineteenth Century America. University Park, TX: Pennsylvania State University Press, 2006.

Josephson, Matthew. The Robber Barons: The Great American Capitalists, 1861-1901. Orlando, FL: Harcourt, 1962 [1934].

Kirkland, Edward Chase. Charles Francis Adams, Jr: The Patrician at Bay, 1835-1915. Cambridge, MA: Harvard University Press, 1965.

- Men, Cities, and Transportation: A Study in New England History, 2 vols. Cambridge, MA: Harvard University Press, 1948.

Klein, Maury. The Life and Legend of Jay Gould. Baltimore: Johns Hopkins University Press, 1986.

Laird, Pamela Walker. Advertising Progress: American Business and the Rise of Consumer Marketing. Baltimore, MD: Johns Hopkins University Press, 1998.

Lamoreaux, Naomi R. The Great Merger Movement in American Business, 1895-1904. Cambridge: Cambridge University Press, 1985.

Latham, Earl, ed. John D. Rockefeller: Robber Baron or Industrial Statesman? Boston: D. C. Heath and Company, 1949.

Licht, Walter. Industrializing America: The Nineteenth Century. Baltimore: Johns Hopkins University Press, 1995.

McCraw, Thomas K. Prophets of Regulation: Charles Francis Adams, Louis D. Brandeis, James M. Landis, Alfred E. Kahn. Cambridge, MA: Belknap Press of Harvard University Press, 1984.

Mill, John Stuart. Principles of Political Economy. Boston: Charles C. Little \& James Brown, 1848.

Mott, Frank Lather. A History of American Magazines: Vol. 3, 1865-1885. Cambridge, MA: Harvard University Press, 1938.

Orbanes, Philip E. Monopoly: The World's Most Famous Game and How It Got That Way. New York: Da Capo Press, 2006.

Postel, Charles. The Populist Vision. New York: Oxford University Press, 2007.

Stiles, T. J. The First Tycoon: Cornelius Vanderbilt. New York: Alfred A. Knopf, 2009.

Thompson, Robert Luther. Wiring a Continent: The History of the Telegraph Industry in the United States, 1832-1866. Princeton: Princeton University Press, 1947.

Usselman, Steven W. Regulating Railroad Innovation: Business, Technology, and Politics in America, 1840-1920. Cambridge: Cambridge University Press, 2002.

Wells, Wyatt. Antitrust and the Formation of the Postwar World. New York: Columbia University Press, 2002.

West, Richard Samuel. Satire on Stone: The Political Cartoons of Joseph Keppler. Urbana: University of Illinois Press, 1988.

White, Richard. Railroaded: The Transcontinentals and the Making of Modern America. New York: W. W. Norton \& Co, 2011.

Zunz, Olivier. Making America Corporate, 1870-1920. Chicago: University of Chicago Press, 1990. 


\section{Articles and Essays}

Bridges, Hal. "The Robber Baron Concept in American History." Business History Review 32 (Spring 1958): 1-13.

Chalmers, David. "From Robber Barons to Industrial Statesmen: Standard Oil and the Business Historians." American Journal of Economics and Sociology 20 (October 1960): 47-58.

Chandler, Alfred D., Jr. "Comparative Business History." In Enterprise and History, edited by D. C. Coleman and Peter Mathias, 3-26. Cambridge: Cambridge University Press, 1984.

Culbertson, Tom. "The Golden Age of American Political Cartoons." Journal of the Gilded Age and Progressive Era 7 (July 2008): 277-95.

Du Boff, Richard B., and Edward S. Herman. "Alfred Chandler's New Business History: A Review." Politics and Society 10 (1980): 87-110.

Dunlavy, Colleen A. "From Citizens to Plutocrats: Nineteenth-Century Shareholder Voting Rights and Theories of the Corporation." In Constructing Corporate America: History, Politics, Culture, edited by Kenneth Lipartito and David Sicilia, 66-93. Oxford: Oxford University Press, 2004.

Dunlavy, Colleen A., and Thomas Welskopp. "Peculiarities and Myths: Comparing U.S. and German Capitalism." German Historical Institute Bulletin 41 (Fall 2007): 33-64.

Galambos, Louis. "Technology, Political Economy, and Professionalization: Central Themes of the Organizational Synthesis." Business History Review 57 (Winter 1983): 471-93.

-. "The Emerging Organizational Synthesis in American History." Business History Review 44 (1970): 279-90.

John, Richard R. "Communications Networks in the United States from Chappe to Marconi." In Media History and the Foundations of Media Studies, edited by John Nerone. Malden, MA: Wiley-Blackwell, 2012, forthcoming.

- "Elaborations, Revisions, Dissents: Alfred D. Chandler's, The Visible Hand after Twenty Years." Business History Review 71 (Summer 1997): 151-200.

- - "Farewell to the "Party Period': Political Economy in NineteenthCentury America," Journal of Policy History 16, no. 2 (2004): 117-25.

-_._. "Governmental Institutions as Agents of Change: Rethinking American Political Development in the Early Republic, 1787-1835." Studies in American Political Development 11 (Fall 1997): 347-80.

—_. "Ruling Passions: Political Economy in Nineteenth-Century America." Journal of Policy History 18, no. 1 (2006): 1-20.

"Telecommunications." Enterprise and Society 9 (September 2008): 507-20.

-. - "Turn̈er, Beard, Chandler: Progressive Historians." Business History Review 82 (Summer 2008); 227-40.

___. "Who Were the Gilders? And Otber Seldom-Asked Questions about Business, Technology, and Political Economy in the United States, 18771900." Journal of the Gilded Age and Progressive Era 8 (October 2009): $474-80$. 
Kemnitz, Thomas Milton. "The Cartoon as a Historical Source." Journal of Interdisciplinary History 4 (Summer 1973): 81-93.

Lipartito, Kenneth. "The Utopian Corporation." In Constructing Corporate America: History, Politics, Culture, edited by Kenneth Lipartito and David B. Sicilia, 94-119. New York: Oxford University Press, 2004.

Skocpol, Theda. "Bringing the State Back in: Strategies of Analysis in Current Research." In Bringing the State Back In, edited by Peter B. Evans, Dietrich Rueschemeyer, and Theda Skocpol, 3-37. Cambridge: Cambridge University Press, 1985.

Thomas, Samuel J. "Mugwump Cartoonists, the Papacy, and Tammany Hall in America's Gilded Age." Religion and American Culture 14 (Summer 2004): 213-50.

—. "Teaching America's GAPE (or Any Other Period) with Political Cartoons: A Systematic Approach to Primary Source Analysis." History Teacher 37 (August 2004): 425-46.

Winner, Langdon. "Do Artifacts Have Politics?" Daedalus 109 (Winter 1980): 121-36.

Wrege, Charles D., and Guidon A. Sorbo, Jr. "A Bridge Builder Changes a Railroad: The Story of Daniel Craig McCallum." Canal History and Technology Proceedings 24 (2005): 183-218.

\section{Magazines and Newspapers}

Collier's, 1905.

Harper’s Weekly, 1865-1900.

Judge, 1881-1900.

Nation, $1865-1900$.

New York Times, 1850-1900.

Portland Oregon Journal, 1913.

Puck, 1877-1900.

Review of Reviews, 1919.

The Daily Graphic: An Illustrated Evening Newspaper [New York], 1873-1889.

Wasp, 1876-1900.

\section{On-Line Cartoon Libraries}

Mark Aldrich. "Railroad Cartoons." http://sophia.smith.edu/ maldrich.

National Humanities Center. "The Image of the Octopus: Six Cartoons 18821909." http://nationalhumanitiescenter.org/pds/gilded/power/text1/text1link. htm.

Terry Cox. "Known Lithographic Caricatures of Major Nineteenth-Century Millionaires." http://www.coxrail.com/puck-judge/full-display.asp. 


\section{ENTERPRISE \& SOCIETY}

THE INTERNATIONAL JOURNAL OF BUSINESS HISTORY

Published by Oxford University Press for the Business History Conference Volume 13, Number 1

March 2012

\section{ARTICLES}

Robber Barons Redux: Antimonopoly Reconsidered

Richard R. John

Labor Makes the News: Newspapers, Journalism, and Organized Labor, 1933-1955

Philip M. Glende

The Proliferation of Brands: The Case of Food in Belgium, 1890-1940

Patricia Van Den Eeckhout and Peter Scholliers

Managing Political Risk in Global Business: Beiersdorf 1914-1990

Geoffrey Jones and Christina Lubinski

The Shareholder Voice: British and American Accents, 1890-1965

Janette Rutterford

Religion, Human Relations, and Union Avoidance in the 1950s: The Electrical Industry's Southern Strategy and Its Limits

Elizabeth Fones-Wolf and Ken Fones-Wolf

\section{REVIEWS}

Donald W. Rogers. Making Capitalism Safe: Work Safety and Health Regulation in America, 1880-1940

Reviewed by Meghan Crnic

Ann Johnson. Hitting the Brakes: Engineering Design and the Production of Knowledge

Reviewed by John A. Heitmann

Janette Thomas Greenwood. First Fruits of Freedom: The Migration of Former Slaves and Their Search for Equality In Worcester, Massachusetts, 1862-1900

Reviewed by Rhonda Ragsdale

David J. Bricknell. Float: Pilkingtons' Glass Revolution 